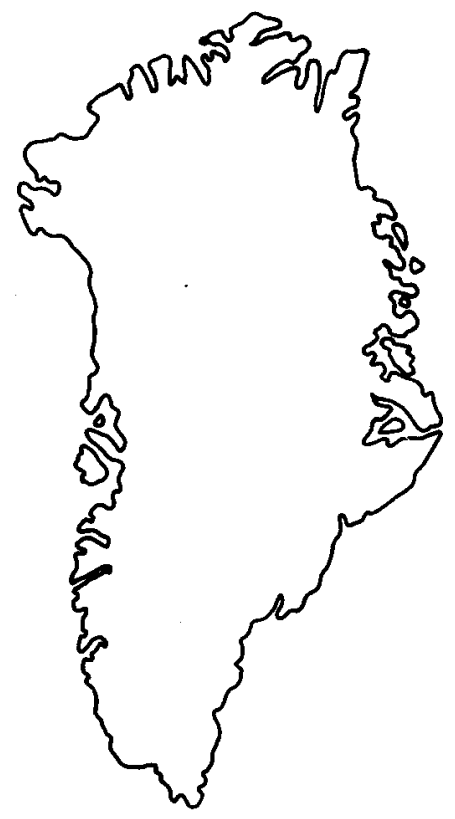

\title{
Upper Palaeozoic fusulinid assemblages, Wandel Sea Basin, North Greenland
}

\author{
Inger Nilsson
}

\begin{abstract}
Eight fusulinid assemblages are recognized in the Mallemuk Mountain Group of North Greenland. They are of late Moscovian (Wedekindellina assemblage), late Kasimovian (Rauserites ex. gr. simplex assemblage), early-middle Gzhelian (Rauserites ex. gr. rossicus assemblage), late Gzhelian - ?early Asselian (Schellwienia arctica assemblage), early Asselian (Sphaeroschwagerina aff. S. vulgaris assemblage), middle-late Asselian (Schwagerina ex. gr. nathorsti assemblage), latest Asselian - earliest Sakmarian (Schwagerina aff. S. moelleri - S. ex. gr. exuberata assemblage) and late Sakmarian (Schwagerina plicatissima assemblage) ages. These assemblages show close similarities to faunas described elsewhere in the present Arctic region, i.e. Arctic Russia, Southwest Barents shelf, Svalbard and Arctic Canada.
\end{abstract}

I. N., IKU Petroleum Research, N-7034 Trondheim, Norway. Present address: Saga Petroleum a.s., Torvet 7, Postboks 1134, N-9401 Harstad, Norway.

Biostratigraphical information from most Upper Palaeozoic deposits of the Wandel Sea Basin in North Greenland is limited (Fig. 1). The zonation of Stemmerik \& Håkansson (1989) is based mainly on biostratigraphic work of Dunbar et al. (1962) and Petryk (1977), with some additional fusulinid datings by J. E. Whittaker (in Stemmerik \& Håkansson, 1989). Additional stratigraphical information has been provided by Nilsson et al. (1991) based on a few fusulinid bearing samples from Peary Land, Prinsesse Ingeborg Halvø and Amdrup Land (Fig. 2). Five fusulinid faunas of late Moscovian, Gzhelian, middle-late Asselian, late Asselian - ?early Sakmarian and late Sakmarian ages were reported.

No documentation of fusulinid faunas has been published from this region, apart from one paper dealing with fusulinids from Holm Land and Amdrup Land (Ross \& Dunbar, 1962). This paper documents the fusulinid faunas presented by Nilsson et al. (1991) and discusses their biostratigraphical relevance to the adjacent areas of Spitsbergen, Bjørnøya and Barents Sea (Finnmark Platform) (Fig. 1). In addition, it includes re-examination of the fusulinid material described by Ross \& Dunbar (1962) from Holm Land and Amdrup Land (the Pseudoschwagerina zone of Dunbar et al., 1962) and Petryk's (1977) material from eastern Peary Land.

\section{Geological framework}

During the Late Palaeozoic North Greenland, together with the Barents Shelf region, formed part of a sedimentary basin which connected westwards to the Sver- drup Basin of Arctic Canada and eastwards to the TimanPechora Basin of Arctic Russia. Sediments of the Mallemuk Mountain Group are exposed in Peary Land in central North Greenland and in Holm Land, Amdrup Land and Prinsesse Ingeborg Halv $\varnothing$ in eastern North Greenland (Fig. 2). They comprise more than $1100 \mathrm{~m}$ of shelf carbonates and siliciclastics with subordinate evaporites (Stemmerik \& Håkansson, 1989; Fig. 2). Deposition probably occurred in small, isolated fault-blocks separated from the stable Greenland craton by major fault zones during the Moscovian and on a more widespread shelf during late Carboniferous - early Permian times (Håkansson \& Stemmerik, 1984; Stemmerik \& Håkansson, 1991; Stemmerik \& Worsley, 1989).

The Mallemuk Mountain Group comprises three formations: the Kap Jungersen Formation, the Foldedal Formation and the Kim Fjelde Formation. Early Moscovian shelf deposits of the Kap Jungersen Formation are present in the southern Holm Land and southern Amdrup Land blocks (Fig. 2). The base of this formation is, however, diachronous as the formation onlaps an irregular midCarboniferous relief. Late Moscovian to Gzhelian shelf deposits of the Kap Jungersen and Foldedal Formations were far more widespread covering Holm Land, southern Amdrup Land, most of Peary Land and possibly also Prinsesse Ingeborg Halvø (Stemmerik \& Håkansson, 1991). During the late Carboniferous the mixed siliciclastic and carbonate deposits were succeeded by rather uniform deposition of shallow water carbonates of the Kim Fjelde Formation (Fig. 2). A continuous carbonate platform was gradually developed along the entire length 


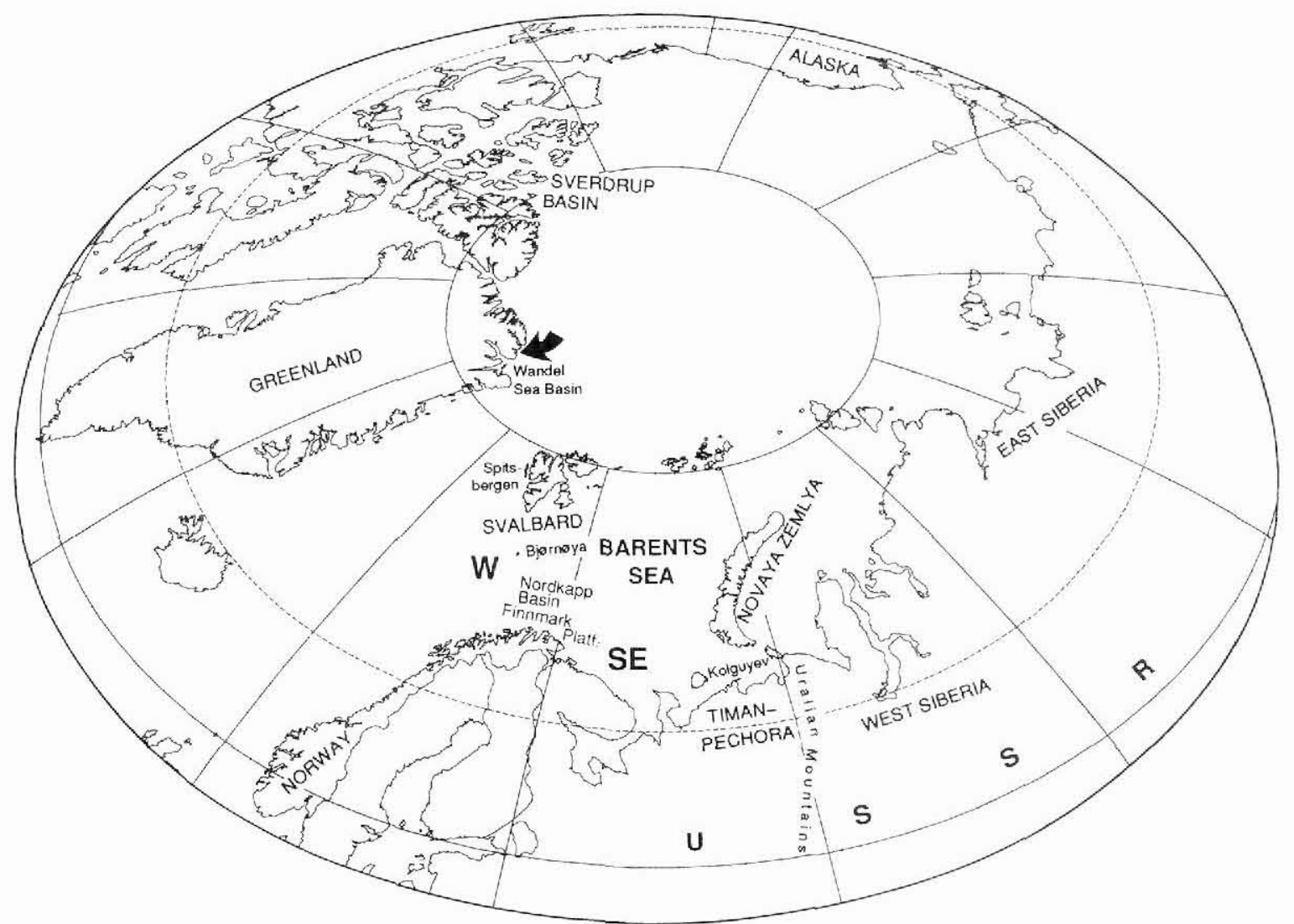

Fig. 1. Locality map in north polar projection showing North Greenland (Wandel Sea Basin), Svalbard (including Bjørnøya), W and SE Barents Sea (Finnmark Platform) and Timan-Pechora Basin of North Russia.

of the Wandel Sea Basin (Stemmerik \& Hăkansson, 1989). Shallowing conditions took place during the Early Permian mainly in Amdrup Land while the depositional basin apparently became gradually deeper during the same time in Peary Land and Prinsesse Ingeborg Halvø (Stemmerik \& Håkansson, 1991).

\section{Fusulinid assemblages}

Fusulinid bearing samples from several sections of North Greenland have been investigated and eight local assemblages have been recognized (Fig. 3). The faunas have been compared with faunas in stratotype areas of the Russian Platform and Urals and to faunas elsewhere in the Arctic region (Fig. 4).

\section{Wedekindellina assemblage (late Moscovian)}

Sample GGU 221386 from the Kim Fjelde Formation in southern Amdrup Land (Fig. 2) comprises Wedekindellina dutkevichi Rauser-Chernousova \& Belyaev, Tait- zehoella librovitchi (Dutkevich), Beedeina paradistenta (Safonova) and Fusulinella ef. F. bocki Möller (Nilsson et al., 1991; Fig. 3). This fauna closely resembles the fauna of the upper Moscovian Wedekindellina zone of Dunbar et al. (1962) from Holm Land and Amdrup Land, and thus suggests an age older than previously proposed for the lower part of the Kim Fjelde Formation in this area (cf. Stemmerik \& Håkansson, 1989).

One sample (GGU 221337) collected in northern Amdrup Land contains poorly preserved specimens of the genus Fusulinella (Nilsson et al., 1991; Fig. 3). This indicates a Middle Carboniferous, possible late Moscovian age for these sediments which previously were believed to be of Early Permian age (cf. Stemmerik \& Håkansson, 1989).

Rauserites ex. gr. simplex assemblage (late Kasimovian)

Fusulinids of Late Carboniferous age ('Triticites' spp. and Pseudofusulinella spp.) have previously been re- 
ported from castern Peary Land (Petryk, 1977; Stemmerik \& Håkansson, 1989). Re-examination of Petryk's collections from the Foldedal Formation shows that the 'Triticites' fauna in the lower part of the section are more primitive than those from the upper part. The assemblage of 'Triticites' spp. in the samples 171, 172, 175 and 182 (see Petryk, 1977) are here assigned to Rauserites ex. gr. simplex (Schellwien), and the Pseudofusulinella spp. belongs to the Pseudofusulinella usvae group (Fig. 3).

Pseudofusulinella usvae (Duktevich) is long-ranging, occurring in Upper Carboniferous strata as well as in Lower Permian beds. Rauserites simplex (Schellwien), however, has a more restricted stratigraphic occurrence. It is present in upper Kasimovian to lower Gzhelian strata
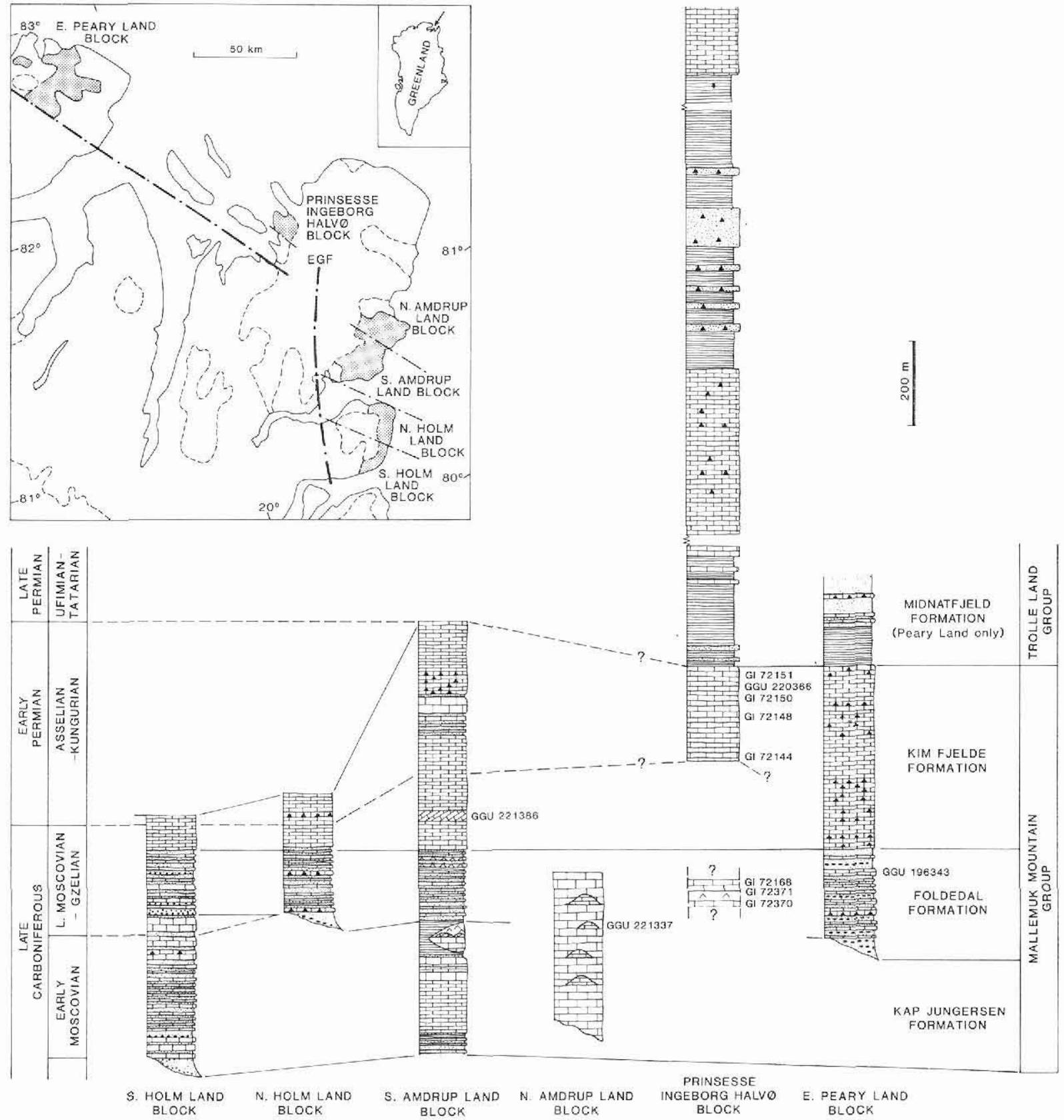

Fig. 2. Lithostratigraphic correlation of marine Upper Palaeozoic sediments in North Greenland with position of the fusulinid bearing samples. Solid lines indicate lithostratigraphic units; dotted line suggested biostratigraphic correlation by Stemmerik \& Håkansson (1989). Inset map shows distribution of Upper Palaeozoic sediments. From Nilsson et al. (1991). 


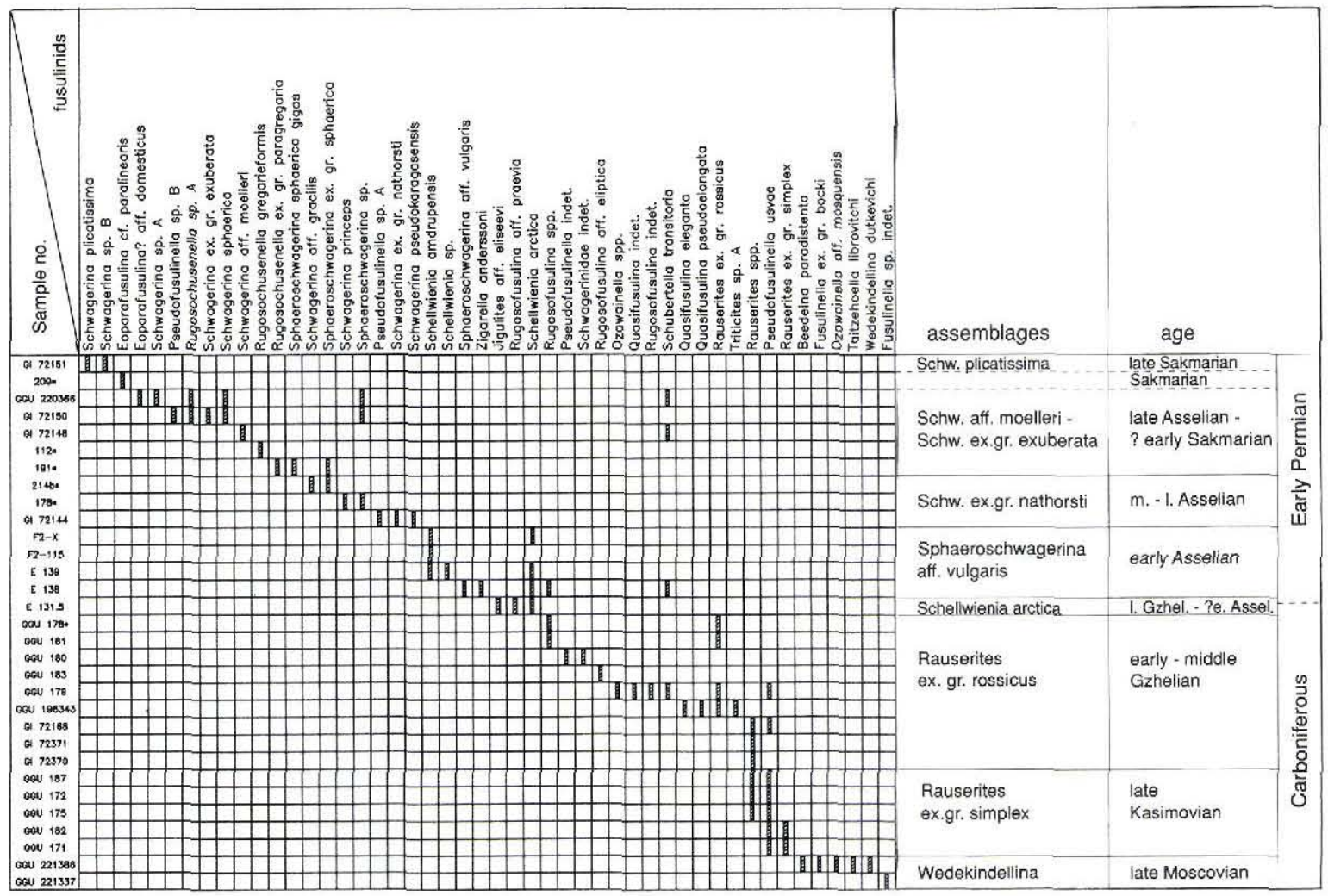

Fig. 3. Composite-distribution chart of fusulinid species from North Greenland. ${ }^{*}=$ loose block.

in the Russian Platform (Rosovskaya, 1958) and the Urals (Davydov in Chuvashov et al., 1986) while only this species is common in upper Kasimovian beds of Spitsbergen (in the Rauserites quasiarcticus zone of Nilsson \& Davydov, 1993).

In the Peary Land section the Rauserites ex. gr. simplex assemblage is overlain by the Rauserites ex. gr. rossicus assemblage, indicating early-middle Gzhelian age (see discussion below). No distinct lower Gzhelian fauna occurs in the Rauserites ex. gr. simplex assemblage and the age of this assemblage is therefore suggested to be no younger than late Kasimovian.

\section{Rauserites ex. gr. rossicus assemblage (early-middle Gzhelian)}

The 'Triticites' fauna stratigraphically higher in the eastern Peary Land section (samples 178, 179, 181, 183 of Petryk, 1977) is more advanced than Rauserites ex. gr. simplex (Schellwien). The investigated specimens show close affinity to Rauserites ex. gr. rossicus (Schellwien). Rauserites rossicus (Schellwien) is an index species in lower Gzhelian strata of the Russian Platform and the Urals, but the species group may also range into middle- upper Gzhelian beds (Rauser-Chernousova et al., 1979). Quasifusulina? sp. and Rugosofusulina aff. $R$. eliptica Rosovskaya occur in the same levels as Rauserites ex. gr. rossicus (Schellwien) (Fig.3). Due to lack of typical upper Gzhelian fusulinids the assemblage is suggested as being of early-middle Gzhelian age.

Sample GGU 196343 from the upper part of the Foldedal Formation in eastern Peary Land contains Rauserites rossicus (Schellwien), Rugosofusulina? sp., Quasifusulina eleganta (Schlykova), Q. pseudoelongata MiklukhoMaclay and Triticites sp. A (Fig. 3). This fauna corresponds well to the beds with the Rauserites ex. gr. rossicus assemblage.

The Rauserites ex. gr. rossicus assemblage is also recognized in the Foldedal Formation of Prinsesse Ingeborg Halvø (samples GI 72168, GI 72370, GI 72371) (Figs 1, 3). The fauna is poor, but it contains Rauserites spp. and Pseudofusulinella usvae (Dutkevich; Fig. 3). The presence of this fusulinid assemblage represents the first evidence of Upper Carboniferous sediments in Kronprins Christian Land (Nilsson et al., 1991). 


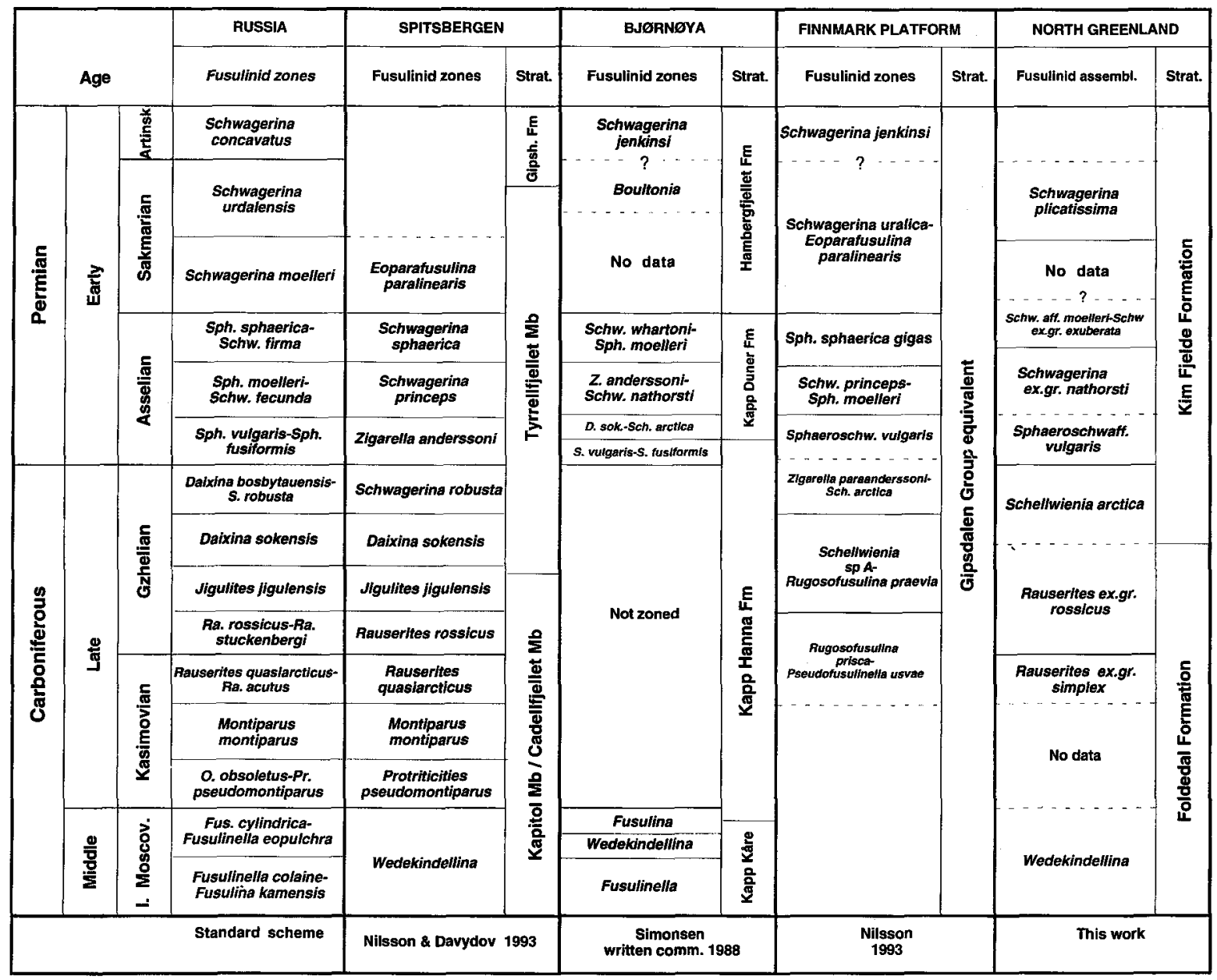

Fig. 4. Biostratigraphical correlation of fusulinid zones in the present Arctic region.

\section{Schellwienia arctica assemblage (late Gzhelian - ?earliest Asselian)}

Schellwienia arctica (Staff \& Wedekind), Schubertella transitoria Staff \& Wedekind and Rugosofusulina sp. are present in the lower part of the 'Pseudoschwagerina' zone of Dunbar et al. (1962) in northern Holm Land (sample E 131 1/2) while Sphaeroschwagerina aff. $S$. vulgaris (Scherbovich) is recognized only in the upper part of the zone (see below). Schellwienia arctica (Schellwien) occurs in upper Gzhelian - lower Asselian beds in Spitsbergen (Nilsson, 1993). This species was previously assigned as an index species for the upper Kasimovian Stage in the Russian Platform and the Urals (e.g. Rauser-Chernousova et al., 1979). The upper Kasimovian specimens of 'Triticites' (i.e. Schellwienia) arcticus have, however, been restudied, and these specimens do not belong to Schellwienia arctica (Schellwien), but to a more primitive species called Rauserites quasiarcticus (Solovieva) (e.g. Davydov et al., 1990).

Species of the genus Rugosofusulina are usually longranging, occurring in Upper Carboniferous - Lower Permian strata. Schubertella transitoria Staff \& Wedekind is also present throughout Upper Carboniferous - lowermost Permian strata. No distinct Asselian fauna occurs in the lower part of the 'Pseudoschwagerina' zone of Dunbar et al. (1962) previously regarded as being of Early Permian age. The Schellwienia arctica assemblage is therefore suggested to be of late Gzhelian - ?earliest Asselian age.

Schellwienia arctica (Staff \& Wedekind) is also recognized in the lower part of the 'Pseudoschwagerina' zone of Dunbar et al. (1962) in southern Amdrup Land (sample F2-X), and this part of the section corresponds to the Schellwienia arctica assemblage of southern Holm Land. 


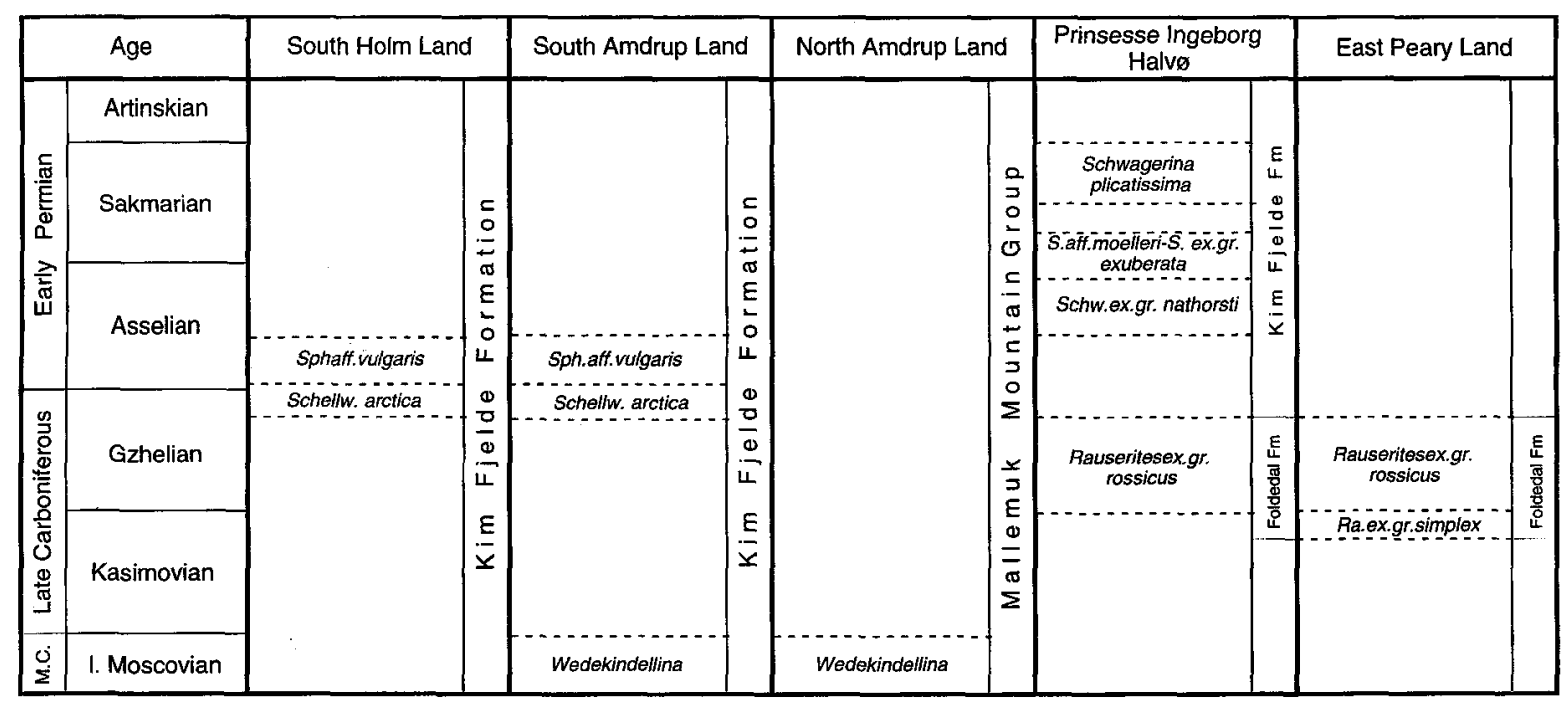

Fig. 5. Fusulinid assemblages and correlation between the investigated localities in North Greenland.

\section{Sphaeroschwagerina aff. S. vulgaris} assemblage (early Asselian)

Sample E-138 in the upper part of 'Pseudoschwagerina' zone of Dunbar et al. (1962) in southern Holm Land includes: Sphaeroschwagerina aff. S. vulgaris (Scherbovich), Schellwienia arctica (Staff \& Wedekind), Zigarella anderssoni (Schellwien) and Schubertella transitoria Staff \& Wedekind. Schellwienia ex. gr. arctica (Staff \& Wedekind) occurs slightly higher in the section (sample E-139).

Sphaeroschwagerina vulgaris (Scherbovich) is an index species for the lower Asselian strata of the Russian Platform and Urals (e.g. Rauser-Chernousova \& Scherbovich, 1958; Davydov et al., 1990). Schellwienia arctica (Staff \& Wedekind) occurs in upper Gzhelian and lower Asselian strata of Spitsbergen (Nilsson, 1993). In Russia this species is most common in upper Gzhelian strata. Zigarella anderssoni (Schellwien) occurs in the uppermost Gzhelian to the middle Asselian in the Urals (Zolotova et al., 1977) while this species characterizes lower Asselian beds in Spitsbergen (Nilsson \& Davydov, 1993, Nilsson 1993). Based on the occurrence of Sphaeroschwagerina aff. S. vulgaris (Scherbovich) and Zigarella anderssoni (Schellwien) the age of the assemblage is assigned to the early Asselian.

In southern Amdrup Land Schellwienia arctica (Staff $\&$ Wedekind) occurs in the lower part of the 'Pseudoschwagerina' zone (sample F2-X in Dunbar et al., 1962) while Schellwienia amdrupensis (Ross \& Dunbar) occurs stratigraphically higher in the section (sample F2-115). Schellwienia amdrupensis (Ross \& Dunbar) is a more advanced form of the genus Schellwienia than S. arctica
(Staff \& Wedekind) and is probably no older than early Asselian age. The strata bearing this species is therefore suggested to correspond to the Sphaeroschwagerina aff. S. vulgaris assemblage of southern Holm Land.

Part of the collections that Ross \& Dunbar (1962) described are from loose blocks. Although these samples have little stratigraphical significance, the recorded faunas give important taxonomic information. One sample (214b) from Amdrup Land (near Sophus Müller Næs) contains Sphaeroschwagerina sp. and Schwagerina ex. gr. gracilis (Sjomina). The former species indicates an Asselian age while the latter species occurs in upper Gzhelian or lower Asselian strata in the Urals and Russian Platform (Davydov in Chuvashov et al., 1986; Davydov et al., 1990). The fauna tentatively belongs to the Sphaeroschwagerina aff. S.vulgaris assemblage.

\section{Schwagerina ex. gr. nathorsti assemblage (middle-late Asselian)}

Sample GI 72144 from Prinsesse Ingeborg Halvø (Kim Fjelde Formation) contains: Schwagerina ex. gr. nathorsti (Staff \& Wedekind), Schwagerina pseudokaragasensis Petocz and Pseudofusulinella sp. B (Fig. 3). In eastcentral Alaska Schwagerina pseudokaragasensis Petocz is identified in beds regarded as being of late Asselian middle Sakmarian age (Petocz, 1970). Schwagerina nathorsti (Staff \& Wedekind) was first described from the Kapp Duner Formation of Bjørnøya (Staff \& Wedekind, 1910), and later studies show that this species is common in middle-upper Asselian beds in Bjørnøya (Simonsen, 1988; Nakrem et al., 1992).

The Schwagerina ex. gr. nathorsti assemblage is sug- 
gested to be of middle-late Asselian age. It is overlain by an assemblage suggested to be of latest Asselian - earliest Sakmarian age (see discussion below).

\section{Schwagerina aff. S. moelleri - Schwagerina} ex. gr. exuberata assemblage (latest Asselian - earliest Sakmarian)

In the upper part of the Kim Fjelde Formation at the Prinsesse Ingeborg Halvø section (GI 72148; Fig. 2) the following species occur: Schwagerina aff. S. moelleri (Schellwien), Eoparafusulina? aff. E. domesticus (Grozdilova \& Lebedeva) and Schubertella transitoria Staff \& Wedekind. Two overlying fusulinid-bearing samples (GI 72150, GGU 220366; Fig. 2) include Sphaeroschwagerina sp., Schwagerina ex. gr. exuberata (Shamov), $S$. ex. gr. sphaerica (Belyaev), S. sp. A, Eoparafusulina? aff. E. domesticus (Grozdilova \& Lebedeva), Rugosochusenella sp. A and Pseudofusulinella sp.

In the Timan-Pechora Basin Schwagerina moelleri (Schellwien) and Eoparafusulina? domesticus (Grozdilova \& Lebedeva) occur in beds of early Sakmarian age (Grozdilova \& Lebedeva, 1961). Schubertella transitoria (Staff \& Wedekind) is long-ranging, occurring in Upper Carboniferous as well as in Lower Permian strata. Sphaeroschwagerina species are common throughout the Asselian in the Urals and Russian Platform but this genus ranges into the Sakmarian in the Timan-Pechora Basin (Konovalova, 1991) and Central Asia (Leven \& Scherbovich, 1978). Schwagerina ex. gr. exuberata (Shamov) occurs in the middle and upper Asselian and $S$. ex. gr. sphaerica (Belyaev) in upper Asselian beds in the Urals and Timan-Pechora Basin (e.g. Mikhailova, 1974; Konovalova, 1991).

The recorded assemblage from the Prinsesse Ingeborg Halvø section comprises a fauna which shows similarities to both upper Asselian and lower Sakmarian strata in Russia. The Schwagerina aff. S. moelleri - Schwagerina ex. gr. exuberata assemblage is tentatively suggested to be of latest Asselian - earliest Sakmarian age.

Sphaeroschwagerina sphaerica gigas (Rauser-Chernousova) and Schwagerina ex. gr. sphaerica (Belyaev) are recognized in a loose block from Amdrup Land (sample 178a). A loose block from Henrik Kröyer Holme (sample 191) contains Sphaeroschwagerina sphaerica gigas (Rauser-Chernousova) and Rugosochusenella ex. gr. paragregaria (Rauser-Chernousova). These faunas show close similarities to the Schwagerina aff. S. moelleriSchwagerina ex. gr. exuberata assemblage of Prinsesse Ingeborg Halvø, and may correspond to that assemblage.
Schwagerina plicatissima assemblage (late Sakmarian)

Schwagerina plicatissima (Rauser-Chernousova) and Schwagerina sp. B occur in the uppermost part of the Kim Fjelde Formation at the Prinsesse Ingeborg Halvø section (GI 72151; Fig. 2). Schwagerina plicatissima (Rauser-Chernousova) is common in upper Sakmarian strata (Schwagerina urdalensis zone) in the Urals and Timan-Pechora Basin (e.g. Konovalova, 1991). The age of the assemblage is therefore regarded to be late Sakmarian.

A loose block from Amdrup Land contains specimens of Eoparafusulina cf. E. paralinearis (Thorsteinsson) (Ross \& Dunbar, 1962). This species is common in beds of early Sakmarian age in Spitsbergen (Cutbill \& Challinor, 1965; Nilsson \& Davydov, 1993) and in Sakmarian strata of Arctic Canada (Thorsteinsson, 1960) and southwestern Barents Shelf (Nilsson, 1993). Eoparafusulina cf. E. paralinearis (Thorsteinsson) may correspond to the upper Sakmarian Schwagerina plicatissima assemblage or slightly older.

\section{Correlation}

Upper Moscovian strata of Holm Land (Foldedal Formation) and Amdrup Land (Foldedal and Kim Fjelde Formations) are characterized by the Wedekindellina assemblage zone which is correlated to the two upper Moscovian fusulinid zones of the stratotype area of the Russian Platform (Rauser-Chernousova et al., 1951; Fig. 4). The upper Moscovian Wedekindellina assemblage zone is also reported from the Kapitol and Cadellfjellet Members of Spitsbergen (Cutbill \& Challinor, 1965; Nilsson, 1988, 1993). Upper Moscovian beds of the Kapp Kåre and Kapp Hanna Formations of Bjørnøya are characterized by three fusulinid assemblages, respectively Fusulinella, Wedekindellina and Fusulina (Simonsen, written communication 1988), and these assemblages contain species which also occur in upper Moscovian beds of the Wandel Sea Basin. Recently, upper Moscovian strata of the Sverdrup Basin (Arctic Canada) were divided into Wedekindellina lata $-W$. uralica longa and Fusulinella eopulchra zones, respectively (Rui Lin et al., 1991). The Wedekindellina assemblage of the Wandel Sea Basin contains similar species as in the two upper Moscovian assemblages of the Sverdrup Basin.

Lower and middle Kasimovian fusulinids have so far not been recognized in North Greenland. The Rauserites ex. gr. simplex assemblage in the Foldedal Formation is suggested to be of late Kasimovian age. The assemblage shows similarities to the fauna in the upper Kasimovian Rauserites quasiarcticus zone in the Kapitol and Cadell- 
fjellet Members in Spitsbergen (Nilsson \& Davydov,1993; Nilsson, 1993). Upper Kasimovian fusulinids have not been reported from the succession of Bjørnøya, and the fauna of the upper Kasimovian - lower Gzhelian Pseudofusulinella - Rugosofusulina ex. gr. prisca assemblage of Finnmark Platform (Nilsson, 1993) shows no close similarities to the Rauserites ex. gr. simplex assemblage of North Greenland.

Lower to middle Gzhelian beds of North Greenland (Foldedal Formation) are characterized by the Rauserites ex. gr. rossicus assemblage. The Rauserites ex. gr. rossicus assemblage includes few species compared to the lower-upper Gzhelian fusulinid assemblages of Spitsbergen. The recorded assemblage corresponds to the Rauserites rossicus and Jigulites jigulensis assemblages of respectively early and middle Gzhelian ages in Spitsbergen (Fig. 4). Gzhelian fusulinid assemblages are not reported from Bjørnøya, and fusulinids belonging to the Schellwienia sp. A - Rugosofusulina praevia assemblage of the Finnmark Platform indicate only a middle-late Gzhelian age.

The Schellwienia arctica assemblage of North Greenland (Kim Fjelde Formation) is suggested to be of late Gzhelian - ?earliest Asselian age in comparison with faunas of Spitsbergen. Schellwienia arctica (Schellwien) occurs in the upper Gzhelian Daixina sokensis and Schwagerina robusta zones as well as in the lower Asselian Zigarella anderssoni zone of the Tyrrellfjellet Member of Spitsbergen (Nilsson \& Davydov, 1993; Nilsson, 1993). The species is also common in uppermost Gzhelian - ?lowermost Asselian Zigarella paraanderssoni Schellwienia arctica zone of the Finnmark Platform (Nilsson, 1993). In Bjørnøya this species is, however, present only in lower Asselian beds (Daixina sokensis Schellwienia arctica zone) of the Kapp Duner Formation (Simonsen, written communication 1988; Nakrem et al., 1992).

The Schellwienia arctica assemblage of North Greenland is overlain by the Sphaeroschwagerina aff. S. vulgaris assemblage which is no older than early Asselian due to the occurrence of Sphaeroschwagerina aff. S. vulgaris (Scherbovich). In Bjørnøya the base of the Asselian is marked by the appearance of the Sphaeroschwagerina fusiformis - S. vulgaris assemblage, and this zone is overlain by the Daixina sokensis - Schellwienia arctica zone (Simonsen, written communication 1988; Nakrem et al., 1992). The Sphaeroschwagerina aff. S. vulgaris assemblage of North Greenland is correlated to these two lower Asselian assemblages of Bjørnøya, and to the lower Asselian Zigarella anderssoni assemblage of Spitsbergen (Nilsson \& Davydov, 1993; Nilsson, 1993; Fig. 4). On the Finnmark Platform the Sphaeroschwagerina aff. S. vulgaris assemblage of Nilsson (1993) correlates well to the Sphaeroschwagerina aff. S. vulgaris assemblage of North Greenland.

Middle to upper Asselian strata of the Kim Fjelde Formation are characterized by the Schwagerina ex. gr. nathorsti assemblage. The recorded assemblage is poor compared to middle and upper Asselian faunas of Spitsbergen, Bjørnøya and the Finnmark Platform. The assemblage is overlain by the Schwagerina aff. S. moelleri - Schwagerina ex. gr. exuberata assemblage, suggested to be of late Asselian - early Sakmarian age. The fauna shows similarities to the upper Asselian Schwagerina sphaerica zone and lower Sakmarian Eoparafusulina paralinearis zone of Spitsbergen, and to the upper Asselian Sphaeroschwagerina sphaerica gigas zone of Finnmark Platform and Schwagerina whartoni - Sphaeroschwagerina moelleri zone of Bjørnøya.

The youngest fusulinid assemblage recorded in the succession of North Greenland (Kim Fjelde Formation) is of late Sakmarian age (Schwagerina plicatissima assemblage). In Spitsbergen the youngest fusulinid assemblage belongs to the lower Sakmarian Eoparafusulina paralinearis zone (Nilsson \& Davydov, 1993; Nilsson, 1993). No distinct Sakmarian fusulinid fauna has been reported from Bjørnøya. The Eoparafusulina paralinearis Schwagerina uralica zone of Finnmark Platform is of general Sakmarian age (Nilsson, 1993). Except for the specimens of Eoparafusulina cf. E. paralinearis (Thorsteinsson) in a loose block from Amdrup Land, there are no close similarities between the Sakmarian fauna of the Finnmark Platform and the Sakmarian fusulinids from North Greenland. However, both faunas include species which are common in the Sakmarian strata of the Urals or Timan-Pechora Basin (see e.g. Grozdilova \& Lebedeva, 1961; Konovalova, 1991).

\section{Summary and conclusions}

Eight fusulinid assemblages are recorded in the Mallemuk Mountain Group, giving a more precise dating of this succession than previously reported.

The recorded fusulinid assembages show close similarities to faunas reported elsewhere in the present Arctic areas; i.e. North Russia, Southwest Barents sea (Finnmark Platform), Spitsbergen and Bjørnøya (Fig. 4).

The base of the Kim Fjelde Formation in Amdrup Land has been dated as late Moscovian (Wedekindellina assemblage) and places the transition from mixed carbonate and siliciclastic deposition to monotonous carbonate platform sedimentation earlier in time than previously supposed (see Håkansson \& Stemmerik, 1989).

Petryk's (1977) collections from Peary Land (Foldedal Formation) contain two different fusulinid assemblages; the lower Rauserites ex. gr. simplex assemblage is of late 
Kasimovian age and the upper Rauserites ex. gr. rossicus assemblage is suggested to be of early-middle Gzhelian age (Fig. 5).

The first evidence of Upper Carboniferous sediments of the Foldedal Formation is found in Prinsesse Ingeborg Halvø (Rauserites ex. gr. rossicus assemblage). Assemblages of middle-late Asselian (Schwagerina ex. gr. nathorsti), late Asselian - earliest Sakmarian (Schwagerina aff. S. moelleri-Schwagerina ex. gr. exuberata) and late Sakmarian (Schwagerina plicatissima) ages have been recognized stratigraphically higher in the succession (Fig. 5). These assemblages give a more precise dating of the upper part of the Kim Fjelde Formation than in other parts of North Greenland.

Re-examination of the 'Pseudoschwagerina' zone of Dunbar et al. (1962) from samples collected in the lower part of the Kim Fjelde Formation in Holm Land and Amdrup Land gives a slightly older age for the lower part of this assemblage than was previously supposed. The 'Pseudoschwagerina' zone is in the present study divided into a Schellwiena arctica assemblage of late Gzhelian ?earliest Asselian age and a Sphaeroschwagerina aff. $S$. vulgaris assemblage of early Asselian age (Fig. 5).

\section{Taxonomic remarks}

Genus Ozawainella Thompson, 1935

Ozawainella aff. O. mosquensis RauserChernousova, 1951

Plate 1, Figs 5, 6, 9

Stratigraphical distribution. Ozawainella mosquensis Rauser-Chernousova is reported in upper lower Moscovian (Kashirskian) and upper Moscovian strata in the Russian Platform (Rauser-Chernousova et al., 1951) and Timan-Pechora Basin (Grozdilova \& Lebedeva, 1961). The species occurs in upper Moscovian (Kapitol Member) of Spitsbergen (Nilsson, 1988).

Occurrence in North Greenland. Amdrup Land, Kim Fjelde Formation, GGU 221386, Wedekindellina assemblage.

Material. Three tangential sections and five randomly oriented sections.
Genus Schubertella Staff \& Wedekind, 1910

Schubertella transitoria Staff \& Wedekind, 1910

Plate 5, Figs 12, 13

1910 Schubertella transitoria Staff \& Wedekind, p. 121, pl 4 , figs 7,8 .

Stratigraphical distribution. Lower Permian in Russia (e.g. Suleimanov, 1949), Middle Carboniferous (upper Moscovian) to Lower Permian (Asselian) strata in Spitsbergen (Nilsson, 1988), Lower Permian (Asselian) strata on Bjørnøya (Simonsen, written communication 1988) and eastern North Greenland (Dunbar et al., 1962; Ross \& Dunbar, 1962).

Occurrence in North Greenland. Prinsesse Ingeborg Halvø, Kim Fjelde Formation, GI 72148 and GGU 220366, Schwagerina aff. S. moelleri - S. ex. gr. exuberata assemblage.

Material. One axial section, two tangential sections and five randomly oriented sections.

\section{Genus Sphaeroschwagerina Miklukho-} Maclay, 1959

Sphaeroschwagerina sphaerica gigas (Rauser-Chernousova \& Scherbovich, 1949) Plate 5, Fig 7

1949 Schwagerina sphaerica var. gigas Rauser-Chernousova \& Scherbovich, p. 101-102, pl. 10, figs 2, 3.

1962 Pseudoschwagerina pavlovi (Rauser-Chernousova) Ross \& Dunbar (part), pl. 7, figs 10, 11.

Stratigraphical distribution. Middle and upper Asselian strata of the Urals (Rauser-Chernousova \& Scherbovich, 1949) and Bjørnøya (Simonsen, written communication 1988), upper Asselian on Finnmark Platform (Nilsson, 1993).

Occurrence in North Greenland. Amdrup Land, Kim Fjelde Formation, sample 178a (loose block) and Henrik Kröyer Holme, sample 191 (loose block) from Dunbar et al. (1962).

Material. One axial oriented section and some randomly oriented sections. 
Sphaeroschwagerina ex. gr. sphaerica (Scherbovich, 1949)

Plate 4, Fig. 11, Plate 5, Fig. 11

Remarks. Ross \& Dunbar (1962) described this species as Pseudoschwagerina pavlovi (Rauser-Chernousova), but the figured specimens in figs 5,8 and 9 in their plate 7 are more closely related to Sphaeroschwagerina ex. gr. sphaerica (Scherbovich, 1949).

Stratigraphical distribution. Sphaeroschwagerina sphaerica (Scherbovich) is an index species for the upper Asselian in the stratotype area of the Urals, although this species group also occurs in middle Asselian strata (Rauser-Chernousova \& Scherbovich, 1949).

Occurrence in North Greenland. Amdrup Land, Kim Fjelde Formation, sample 214b (loose block) from Ross \& Dunbar (1962), and Henrik Kröyer Holme, sample 191 (loose block) from Dunbar et al. (1962).

Material. One axial oriented section and some oblique oriented sections.

\section{Sphaeroschwagerina aff. S. vulgaris} (Scherbovich, 1949)

Plate 3, Fig. 10

Stratigraphical distribution. Lower Asselian beds of the Urals (Rauser-Chernousova \& Scherbovich, 1949), Timan-Pechora Basin (Konovalova, 1991), Bjørnøya (Simonsen, written communication 1988; Nakrem et al., 1992) and Finnmark Platform (Nilsson, 1993).

Occurrence in North Greenland. Southern Holm Land, Kim Fjelde Formation, sample E 138 from Ross \& Dunbar (1962).

Material. One slightly oblique oriented section and some randomly oriented sections.

\section{Sphaeroschwagerina sp.}

Plate 5, Figs 5, 8, 10, 14

Remarks. The investigated shells are rather compressed and damaged in the outer volutions, but the specimens have a tightly coiled juvinarium of four volutions. Proloculus is minute. Small chomata are present on the inner four volutions. The spirotheca is thin in the juvinarium, thickening rapidly in the succeeding volutions. Because of the damaged tests it is impossible to determine the pattern of the septal-fluting.
The recorded specimens show close similarities to forms of the genus Sphaeroschwagerina.

Stratigraphical distribution. Sphaeroschwagerina is present in the Lower Permian (Asselian to Sakmarian) (e.g. Loeblich \& Tappan, 1988).

Occurrence in North Greenland. Prinsesse Ingeborg Halv $\varnothing$, Kim Fjelde Formation, GGU 220366, GI 72150, Schwagerina aff. S. moelleri - S. ex. gr. exuberata assemblage.

Material. Ten randomly oriented sections.

\section{Genus Fusulinella von Möller, 1877}

Fusulinella ex. gr. bocki Möller, 1877

Plate 1, Fig. 4

Stratigraphical distribution. Fusulinella bocki Möller occurs in upper Moscovian strata on the Russian Platform (Rauser-Chernousova et al., 1951), Timan (Lebedeva, 1966), Spain (van Ginkel, 1965), Bjørnøya (Simonsen, written communication 1988) and Spitsbergen (Nilsson, 1988).

Occurrence in North Greenland. Amdrup Land, Kim Fjelde Formation, GGU 221386, Wedekindellina assemblage.

Material. One randomly oriented section.

\section{Plate 1}

Figs 1,3. Wedekindellina dutkevichi Rauser-Chernousova \& Belyaev; 1, 3, GGU 221386, × 20.

Figs 2,7. Beedeina paradistenta (Safanova); 2, 7, GGU 221386, $\times 20$.

Fig. 4. Fusulinella ex. gr. bocki Möller; 4, GGU 221386, $\times 20$.

Figs 5,6,9. Ozawainella aff. mosquensis Rauser-Chernousova; $5,6,9$, GGU 221386, $\times 40$.

Figs 8,11. Taitzehoella librovitchi (Dutkevich); 8, 11, GGU $221386, \times 20.3$.

Figs 10,12,15,18. Rauserites aff. $R$. simplex (Schellwien); 10, 12, 15, 18, sample 182 of Petryk (1977), $\times 10$.

Figs $13,14,16,17$. Rauserites aff. $R$. irregularis (Schellwien \& Staff); 13, sample 172 of Petryk (1977); 14, 16, sample 182 of Petryk (1977); 17, sample 171 of Petryk (1977), $\times 10$.

Fig. 19. Pseudofusulinella sp. A; 19, sample 181 of Petryk (1977), $\times 10$.

Figs 20-22. Pseudofusulinella usvae (Dutkevich); 20, 21, sample 187 of Petryk (1977), $\times 10 ; 22$, the same $\times 20$. 

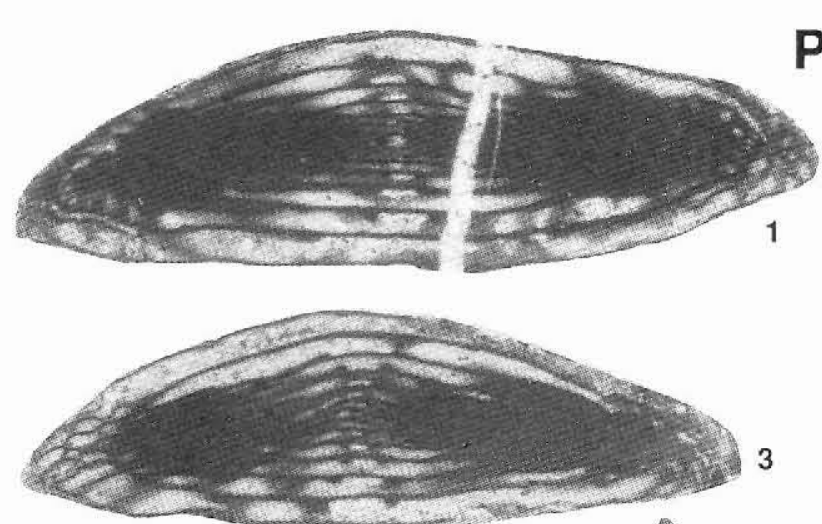

Plate 1
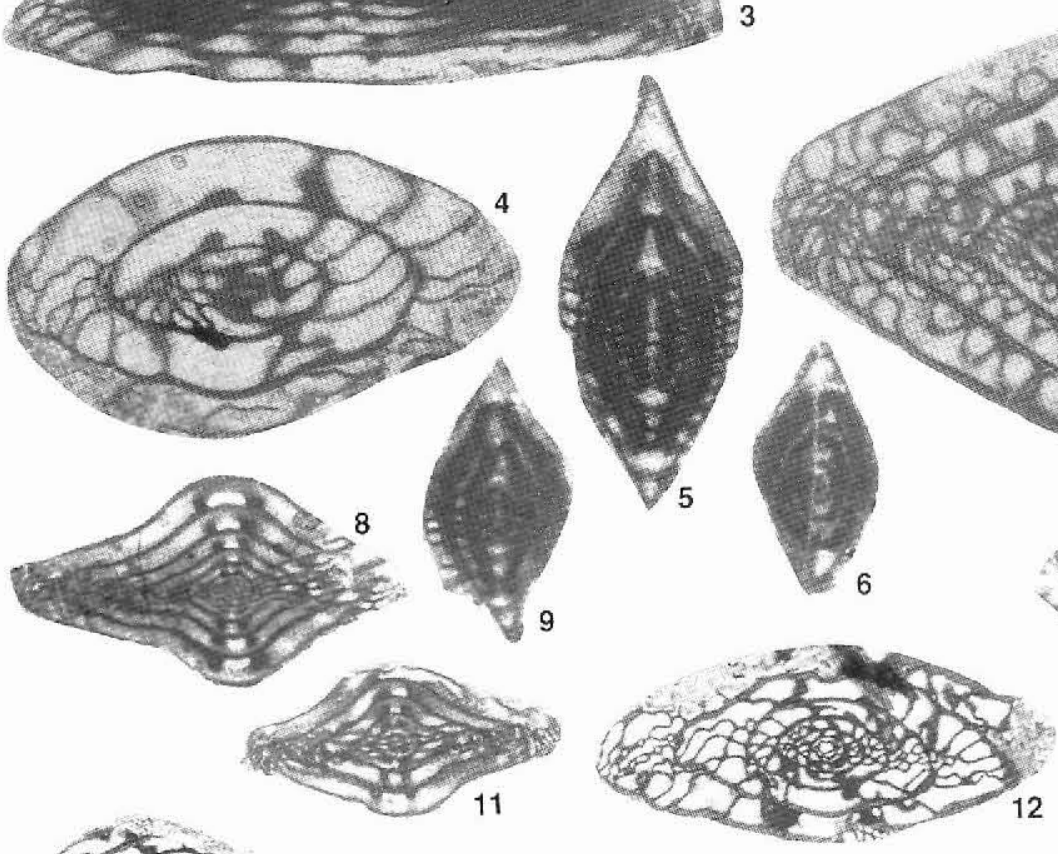

-
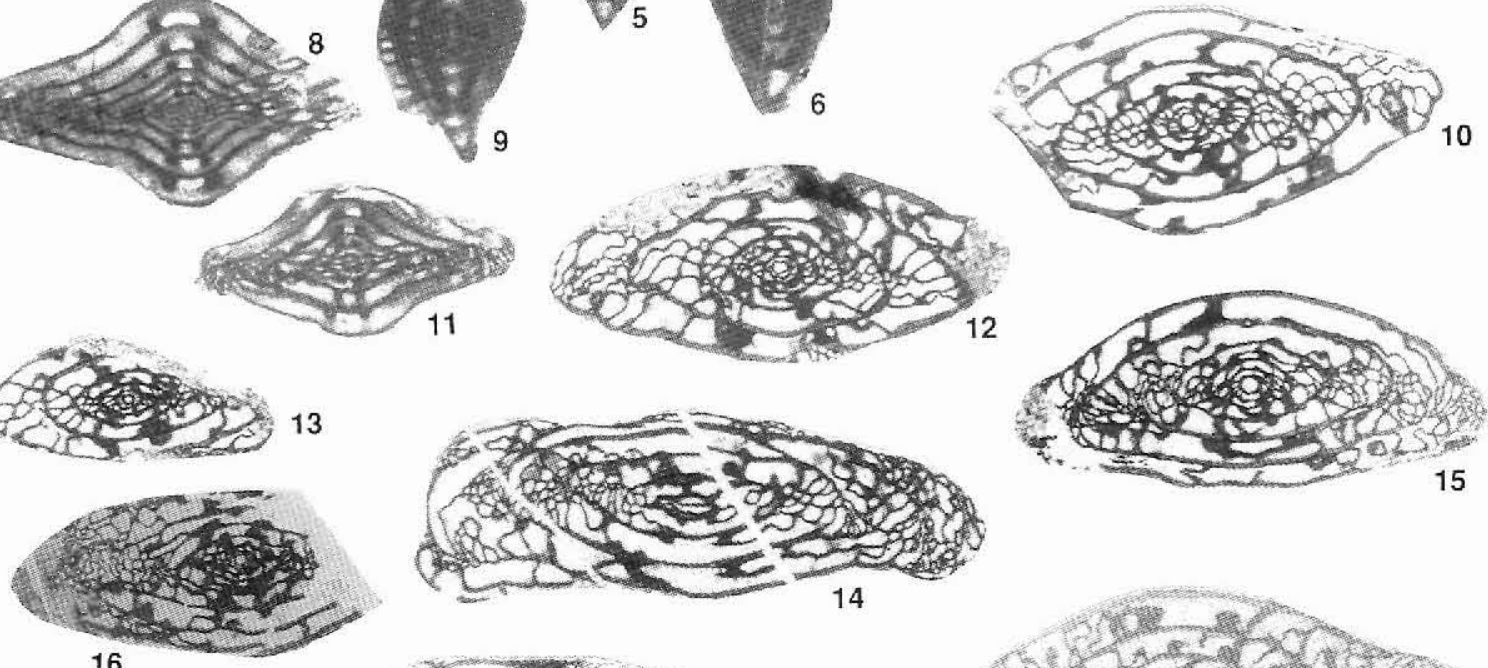

15

16
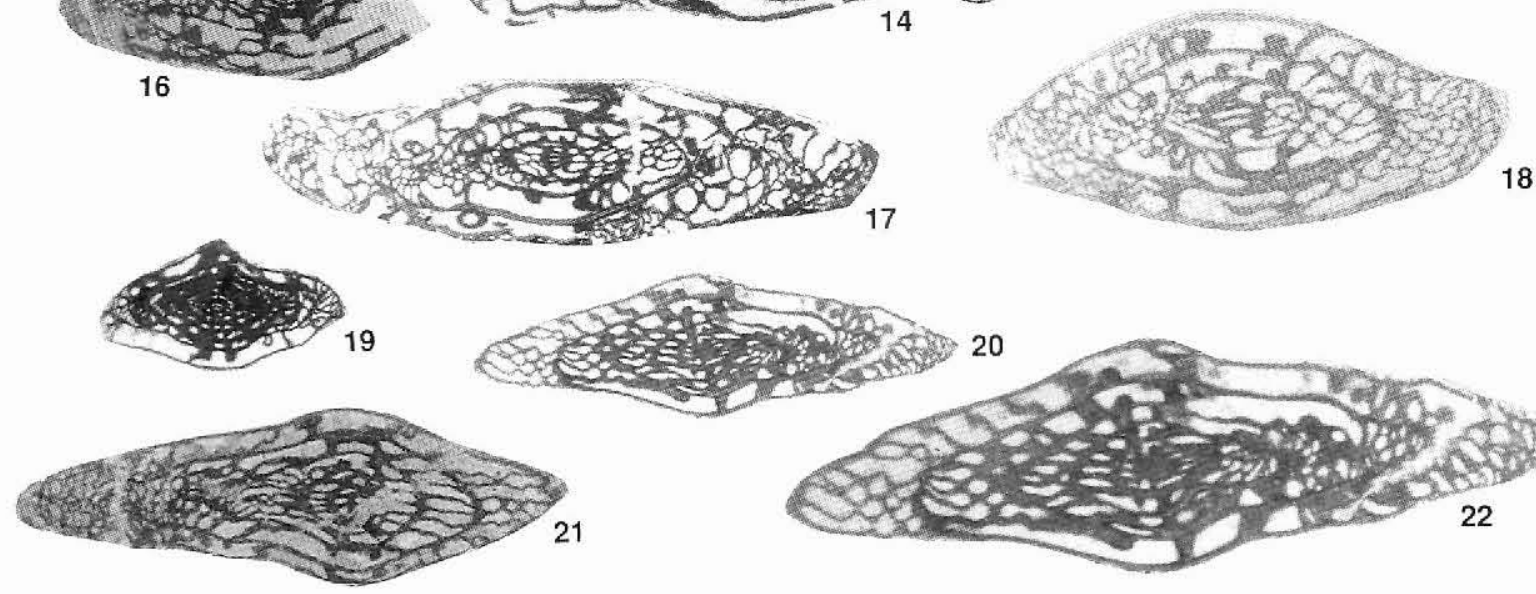
Genus Pseudofusulinella Thompson, 1951 Pseudofusulinella usvae (Dutkevich, 1932) Plate 1, Figs 20-22; Plate 2, Fig. 12

1932 Fusulinella usvae Dutkevich, p. 15-16, no illustration. 1934 Fusulinella usvae Dutkevich, p. 53-57 Russian, p. 88-80 English, pl. 6, figs 1-11.

Stratigraphical distribution. Upper Carboniferous and Lower Permian (Asselian-Sakmarian) strata in Russia (e.g. Rauser-Chernousova et al., 1979) and Spitsbergen (Nilsson, 1993).

Occurrence in North Greenland. Prinsesse Ingeborg Halvø, Foldedal Formation, GI 72168, Rauserites ex. gr. rossicus assemblage.

Material. Two tangential oriented sections and some randomly oriented sections.

\section{Pseudofusulinella sp. A}

Plate 1 , Fig. 19

Remarks. A specimen of 6 volutions reaches a length of $4.2 \mathrm{~mm}$ and a diameter of $1.0 \mathrm{~mm}$. It is different from the Pseudofusulinella usvae group in having more intensively fluted septa at the pole regions, more massive chomata and a more elongated test.

Stratigraphical distribution. Pseudofusulinella species is usually long ranging, occurring in Upper Carboniferous as well as in Lower Permian (Asselian-Sakmarian) strata (e.g. Loeblich \& Tappan, 1988).

Occurrence in North Greenland. Prinsesse Ingeborg Halvø, Kim Fjelde Formation, GI 72144, Schwagerina ex. gr. nathorsti assemblage.

Material. One slightly tangential oriented section.

\section{Pseudofusulinella sp. B}

Plate 5, Fig. 9

Remarks. Only randomly oriented specimens were examined. The shape of the test seems to be inflated fusiform with bluntly to sharply pointed poles. Number of volu- tions is 7. Pseudofusulinella sp. B is different from Pseudofusulinella ex. gr. usvae in having a shorter and more inflated fusiform shape. Pseudofusulinella sp. B is shorter and more globose than Pseudofusulinella sp. A.

Stratigraphical distribution. Upper Carboniferous Lower Permian (Asselian-Sakmarian) strata (eg. Loeblich \& Tappan, 1988).

Occurrence in North Greenland. Prinsesse Ingeborg Halv $\emptyset$, Kim Fjelde Formation, GI 72150, Schwagerina aff. $S$. moelleri $-S$. ex. gr. exuberata assemblage.

Material. Three randomly oriented sections.

\section{Pseudofusulinella sp. C}

Plate 4, Fig. 6

Stratigraphical distribution. Upper Carboniferous to Lower Permian (Asselian-Sakmarian) strata (eg. Loeblich \& Tappan, 1988).

Occurrence in North Greenland. Prinsesse Ingeborg Halvø, Kim Fjelde Formation, GI 72144, Schwagerina ex. gr. nathorsti assemblage.

Material. One tangential oriented section.

\section{Plate 2}

All figures $\times 10$, except noted

Figs 1-3. Rugosofusulina aff. R. eliptica Rosovskaya; 1, 2, 3, sample 183 of Petryk (1977).

Figs 4-10. Rauserites ex. gr. rossicus (Schellwien); 4, sample 181 of Petryk (1977); 6, sample 17810 of Petryk (1977); 5,7-10, GGU-196343.

Figs 11,14. Rauserites sp.; 11, 14, GI 72168.

Fig. 12. Pseudofusulinella aff. usvae (Dutkevich); 12, GI 72168 , $\times 20$.

Fig. 13. Triticites sp. A; 13, GGU 196343.

Fig. 15. Quasifusulina pseudoelongata Miklukho-Maclay; 15, GGU 196343.

Figs 16-17. Quasifusulina eleganta Schlykova; 16, 17, GGU 196343. 


\section{Plate 2}
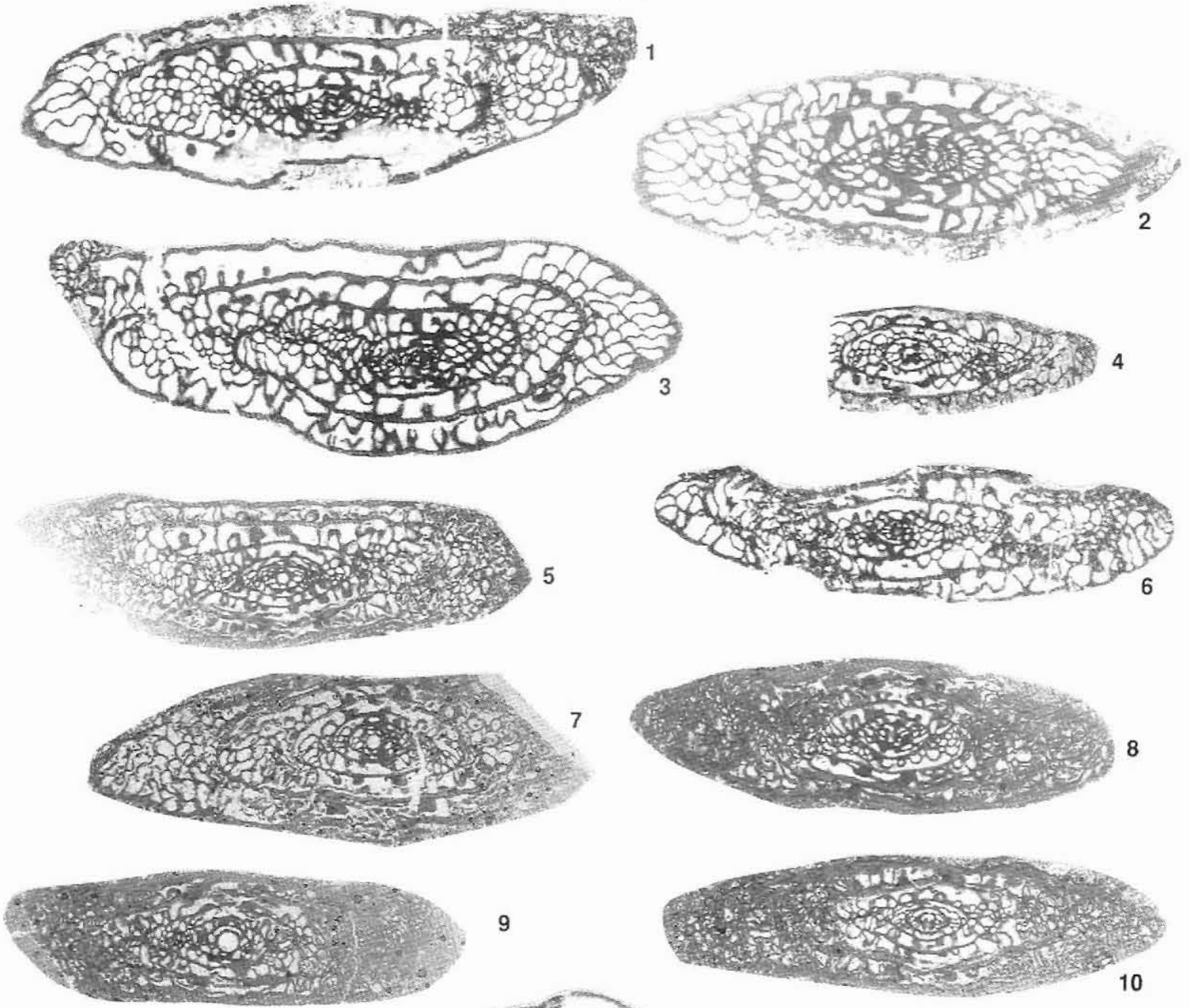

9
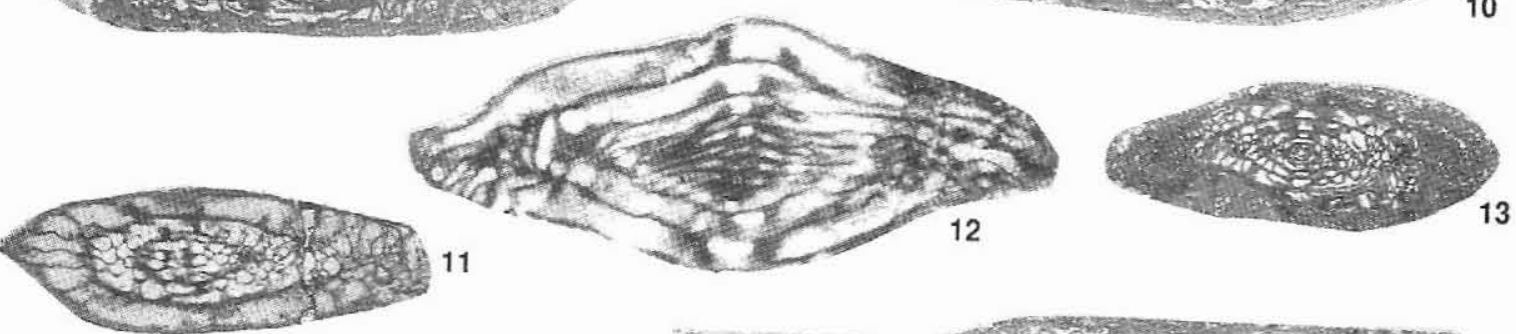

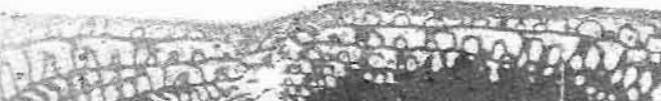

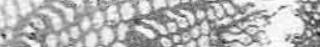

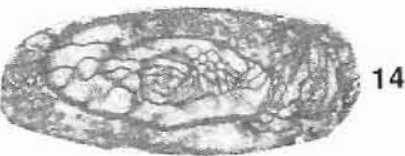

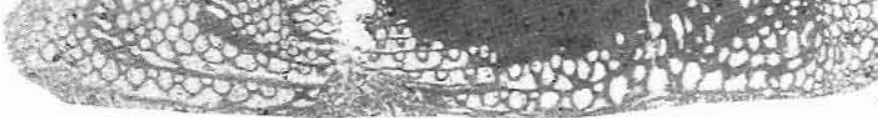
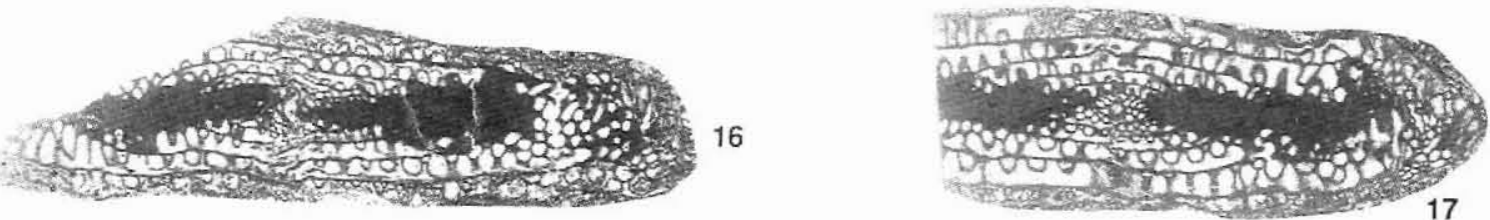
Genus Taitzehoella Sheng, 1951

Taitzehoella librovitchi (Duktevich, 1934)

Plate 1, Figs 8, 11

1934 Fusulinella librovitchi Dutkevich, p. 43, 81, pl. 5, figs $1-5$.

1958 Taitzehoella librovitchi (Dutkevich) Sheng, p. 84, no illustration.

Stratigraphical distribution. This species was orginally described from the Moscovian stage of the Urals (Dutkevich, 1934). The species has earlier been reported in upper Moscovian strata from Holm Land of eastern North Greenland (Dunbar et al., 1962; Ross \& Dunbar, 1962).

Occurrence in North Greenland. Amdrup Land, Kim Fjelde Formation, GGU 221386, Wedekindellina assemblage.

Material. Three slightly tangential oriented sections.

Genus Beedeina Galloway, 1933

Beedeina paradistenta (Safonova, 1951)

Plate 1, Figs 2, 7

1951 Fusulina paradistenta Safonova in RauserChernousova et al., p. 291, pl. 48, figs $3,4$.

Stratigraphical distribution. Upper Moscovian in the Russian Platform (Rauser-Chernousova et al., 1951), 'Lower Marine Group' (i.e. lower Mallemuk Mountain Group) in eastern North Greenland (Dunbar et al., 1962; Ross \& Dunbar, 1962).

Occurrence in North Greenland. Amdrup Land, Kim Fjelde Formation, GGU 221386, Wedekindellina assemblage.

Material. Two axial oriented sections, two slightly tangential oriented sections and several randomly oriented sections.

\section{Genus Quasifusulina Chen, 1934}

Quasifusulina eleganta Schlykova, 1948

Plate 2 , Figs 16,17

1948 Quasifusulina longissima var. eleganta Schlykova, p, 131-132, pl. 6, figs 3-6.

1958 Quasifusulinqa eleganta (Schlykova) Rosovskaya, p. 77 , pl. 1, figs 2,3 .

Stratigraphical distribution. Upper Carboniferous in Russia (Rosovskaya, 1958; Grozdilova, 1966), Upper Carboniferous - Lower Permian in Carnic Alps (Kahler, 1973).
Occurrence in North Greenland. Peary Land, Foldedal Formation, GGU 196343, Rauserites ex. gr. rossicus assemblage.

Material. Three axial oriented sections and two tangential oriented sections.

\section{Quasifusulina pseudoelongata Miklukho- Maclay, 1949}

Plate 2, Fig. 15

1949 Quasifusulina longissima var. pseudoelongata Miklukho-Maclay, p. 62-63, pl. 1, figs 3, 4.

1958 Quasifusulina pseudoelongata (Miklukho-Maclay) Rosovskaya, p. 78, pl. 1, fig. 4.

Stratigraphical distribution. Upper Carboniferous (Kasimovian) in Russia (Rosovskaya, 1958; Grozdilova, 1966), Upper Carboniferous and Lower Permian in Carnic Alps (Kahler, 1973).

Occurrence in North Greenland. Peary Land, Foldedal Formation, GGU 196343, Rauserites ex. gr. rossicus assemblage.

Material. One axial oriented section.

\section{Plate 3}

All figures $\times 10$.

Figs 1-4. Rugosofusulina aff. $R$. praevia Shlykova; $1-4$, sample E131 1/2 of Ross \& Dunbar (1962).

Fig. 5. Jigulites aff. J. eliseevi Mikhailova; 5, sample E131 1/2 of Ross \& Dunbar (1962).

Figs 6-9,11. Schellwienia arctica (Schellwien); 6, 7, sample E131 1/2 of Dunbar et al. (1962); 8, 9, 11, sample E138 of Dunbar et al. (1962).

Fig. 10. Sphaeroschwagerina aff. S. vulgaris (Scherbovich); 10, sample E138 of Dunbar et al. (1962).

Figs 12,15,17. Schellwienia amdrupensis (Ross \& Dunbar); 12, 15, sample E139 of Dunbar et al. (1962); 17, sample $\mathrm{F}_{2}-115$ (holotype) of Ross \& Dunbar (1962).

Figs 13,14,16. Rugosofusulina arianica Leven \& Scherbovich; 13, 14, 16, sample E138 of Dunbar et al. (1962).

Fig. 18. Zigarella anderssoni (Staff \& Wedekind); 18, sample E138 of Dunbar et al. (1962). 


\section{Plate 3}
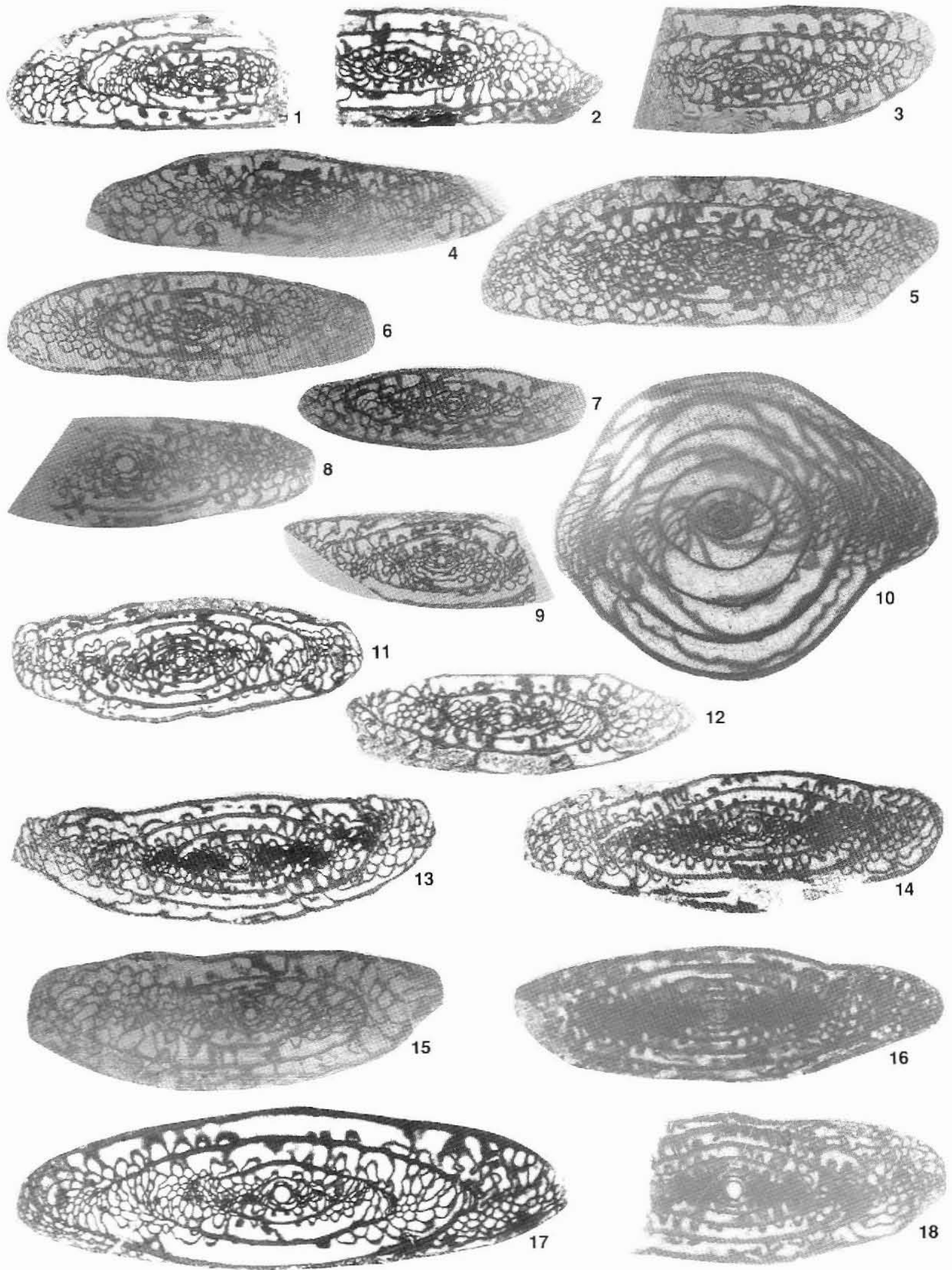
Genus Wedekindellina Dunbar \& Henbest, 1933

Wedekindellina dutkevichi Rauser-

Chernousova \& Belyaev, 1936

Plate 1, Figs 1, 3

1936 Wedekindellina dutkevichi Rauser-Chernousova \& Belyaev, p.183, 185, no illustration.

Stratigraphical distribution. Upper Moscovian in the Russian Platform (Rauser-Chemousova et al., 1951), Timan (Lebedeva, 1966), 'Lower Marine Group' (i.e. lower Mallemuk Mountain Group) in eastern North Greenland (Dunbar et al., 1962; Ross \& Dunbar, 1962), Cadellfjellet and Kapitol Members of the Nordenskiöldbreen Formation in Spitsbergen (Cutbill \& Challinor, 1965; Cutbill, 1968; Nilsson, 1988) and upper part of Kapp Kåre Formation on Bjørnøya (Simonsen, written communication 1988).

Occurrence in North Greenland. Amdrup Land, Kim Fjelde Formation, GGU 221386, Wedekindellina assemblage.

Material. One axial oriented section and several randomly oriented sections.

\section{Genus Triticites Girty, 1904 \\ Triticites sp. A}

Plate 2, Fig. 13

Remarks. Specimen of 6.5 volutions reaching a length of $3.8 \mathrm{~mm}$ and a diameter of $1.4 \mathrm{~mm}$; form ratio of 2.7 . Outside diameter of proloculus measures 100 microns.

Occurrence in North Greenland. Peary Land, Foldedal Formation, GGU 196343, Rauserites ex. gr. rossicus assemblage.

Material. One axial oriented section and two oblique oriented sections.

Genus Jigulites Rosovskaya, 1950

Jigulites aff. J. eliseevi (Mikhailova, 1974)

Plate 3, Fig. 5

Stratigraphical distribution. Upper Gzhelian (Daixina sokensis zone) to lower Asselian (Sphaeroschwagerina fusiformis - S. vulgaris zone) in the Urals (Mikhailova, 1974) and upper Gzhelian in Spitsbergen (Nilsson, 1993).
Occurrence in North Greenland. Southern Holm Land, Kim Fjelde Formation, sample E-131 1/2 of Ross \& Dunbar (1962), Schellwienia arctica zone.

Material: One axial oriented section.

Genus Rauserites Rosovskaya, 1949

Rauserites aff. R. irregularis (Schellwien \& Staff, 1912)

Plate 1, Figs $13,14,16,17$

Stratigraphical distribution. Upper Kasimovian in the Urals (Rosovskaya, 1958).

Occurrence in North Greenland. Peary Land, Foldedal Formation, samples 171, 172 and 182 of Petryk (1977), Rauserites ex. gr. simplex assemblage.

Material. Two oblique oriented and three tangential oriented sections.

Rauserites ex. gr. rossicus (Schellwien, 1908)

Plate 2, Figs 4-10

Stratigraphical distribution. Upper Carboniferous (Gzhelian) strata in Russia (e.g. Rosovskaya, 1958; RauserChernousova et al., 1979); lower Gzhelian in Spitsbergen (Nilsson, 1993).

Occurrence in North Greenland. Peary Land, Foldedal Formation, GGU 196343, Rauserites ex. gr. rossicus assemblage.

\section{Plate 4}

All figures $\times 10$, except noted

Figs 1-3. Schwagerina pseudokaragasensis Petocz; 1, 2, 3, GI-72144.

Figs 4,5,7. Schwagerina ex. gr. nathorsti (Staff \& Wedekind); 4, 5, 7, GI-72144.

Fig. 6. Pseudofusulinella sp. C; 6, GI-72144, $\times 20$.

Fig. 8. Schwagerina aff. S. moelleri (Schellwien); 8, GI-72148.

Figs 9,10,13. Schwagerina aff. S. gracilis (Sjomina); 9, 10, 13, sample 214b of Dunbar et al. (1962).

Fig. 11. Sphaeroschwagerina ex. gr. sphaerica (Scherbovich); 11, sample $214 \mathrm{~b}$ of Dunbar et al. (1962).

Figs 12,16. Schwagerina sp. A; 12, 16, GGU-220366.

Fig. 14. Schwagerina sphaerica (Belyaev); 14, GI-72150.

Figs 15,17,18. Schwagerina ex. gr. princeps (Ehrenberg, sensu Dunbar \& Skinner); 15, 17, sample 178 of Dunbar et al. (1962); 18, GGU-220366. 


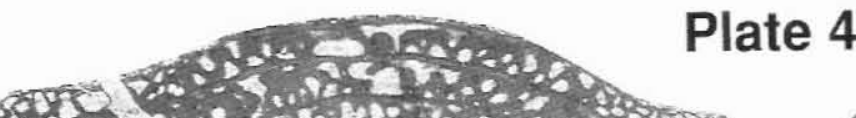
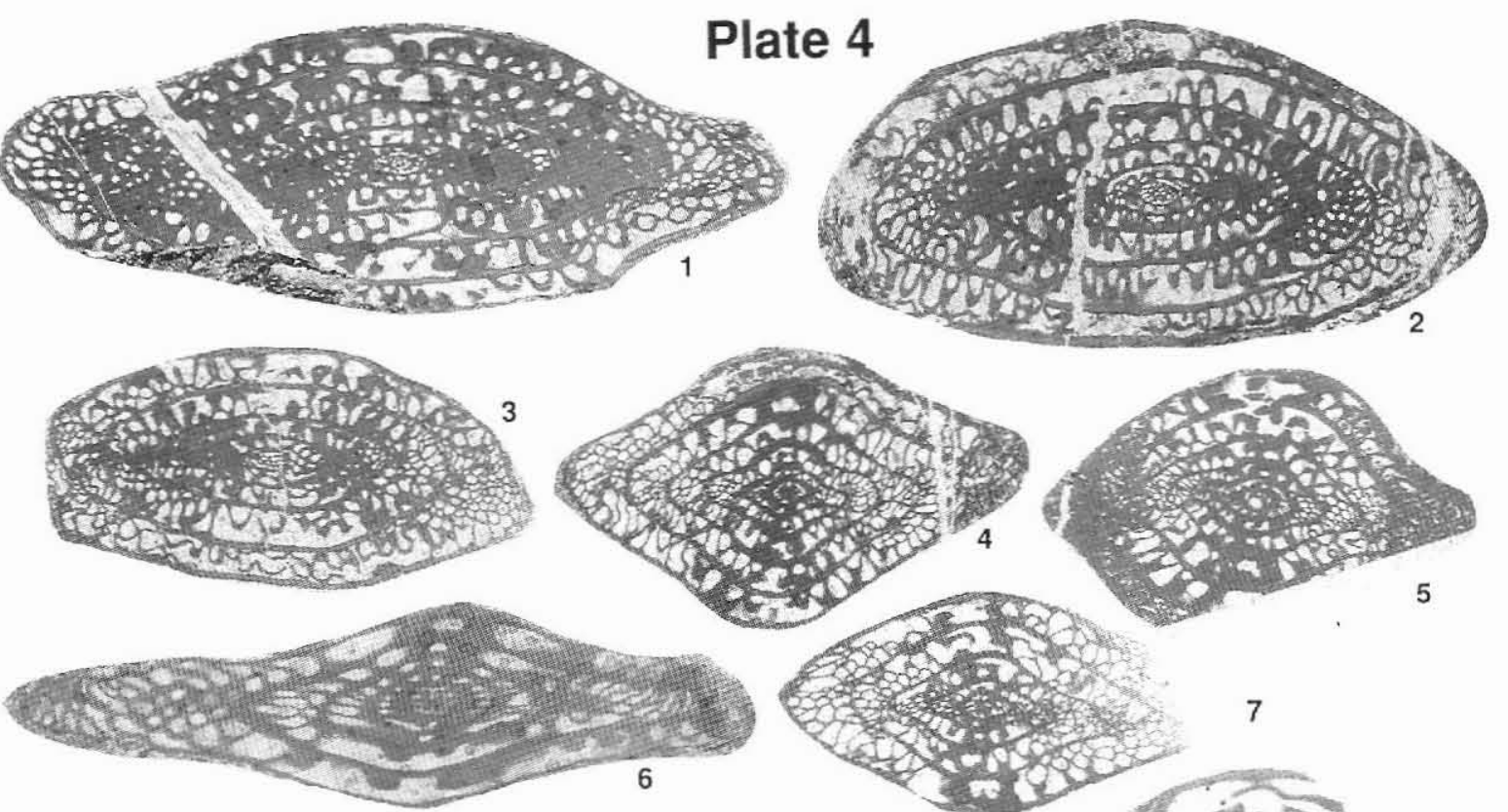

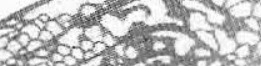

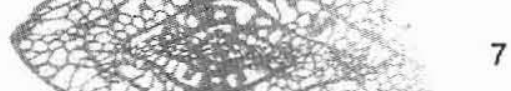

Q

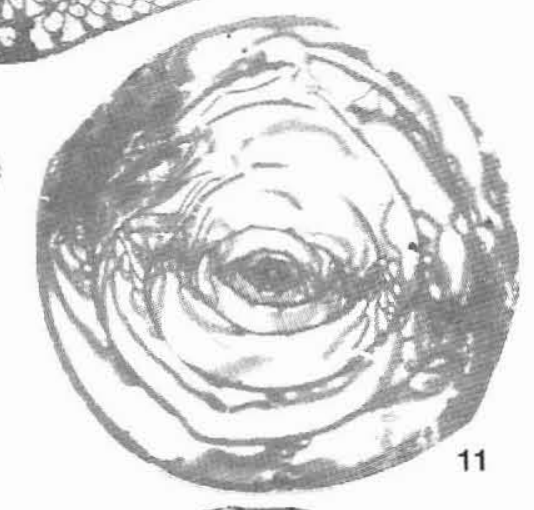

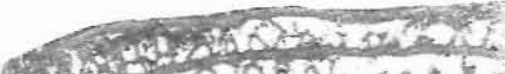

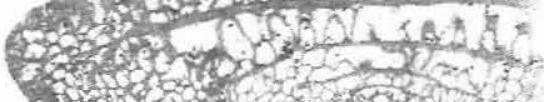

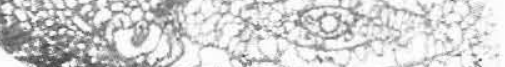
$4.6 x^{2} x^{2}+y^{2} y^{2} 8$
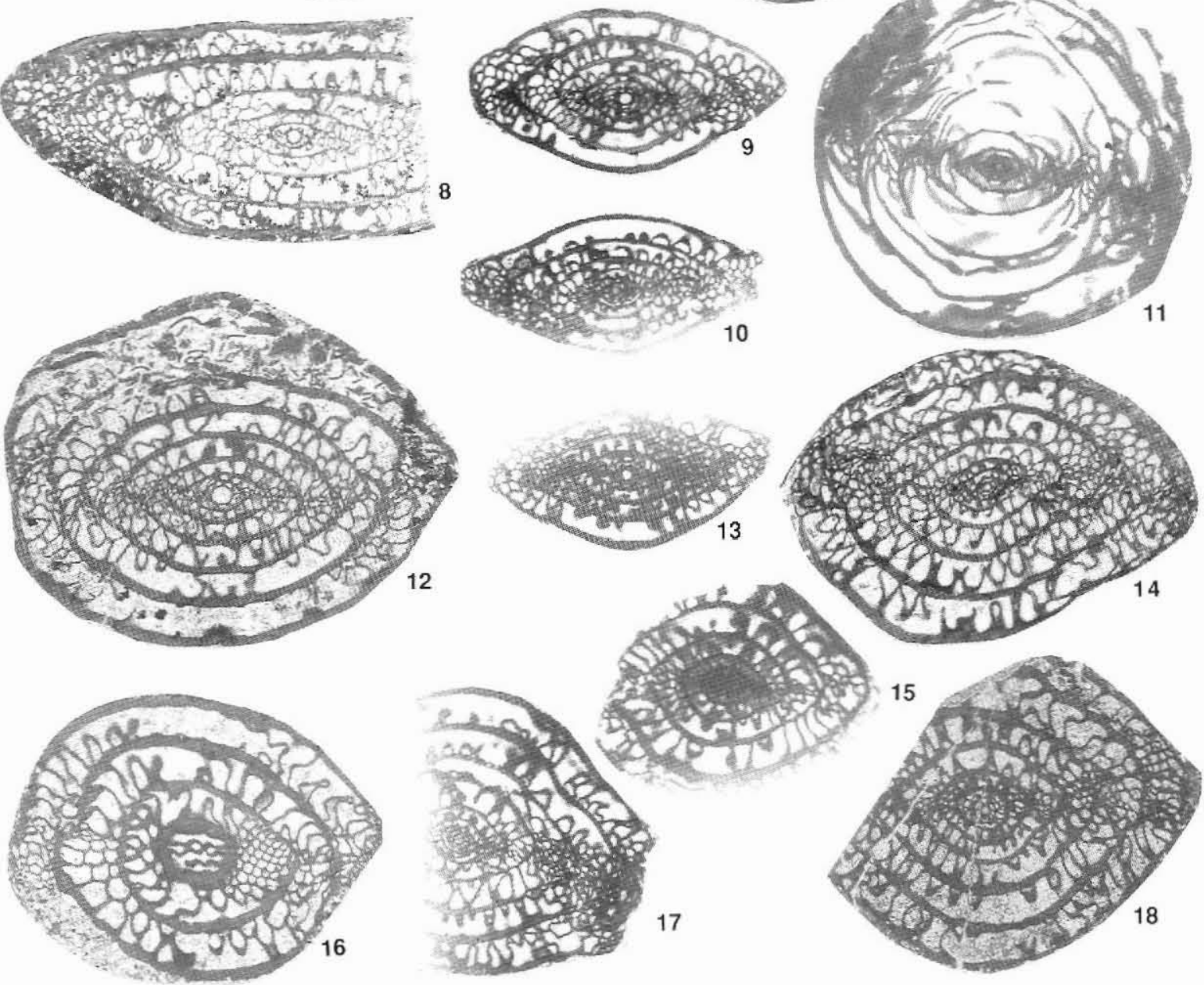
Material. Six axial oriented sections, two slightly tangential oriented sections and several randomly oriented sections.

\section{Rauserites aff. $R$. simplex (Schellwien, 1908)}

Plate 1, Figs 10, 12, 15, 18

Stratigraphical distribution. Upper Kasimovian and lower Gzhelian in the Russian Platform (Rauser-Chernousova, 1938; Rosovskaya, 1958; Mikhailova, 1974) and the Urals (Davydov, 1986), upper Kasimovian (Cadellfjellet and Kapitol Members) in Spitsbergen (Nilsson, 1993).

Occurrence in North Greenland. Peary Land, Foldedal Formation, samples 171, 182 and 175 of Petryk (1977), Rauserites ex. gr. simplex assemblage.

Material. Two axial oriented sections and some oblique oriented sections.

\section{Rauserites sp.}

Plate 2, Figs 11, 14

Remarks. The recorded species show affinities to primitive Rauserites species which are common in upper Kasimovian to lower Gzhelian strata in the Russian Platform (see e.g. Rosovksaya, 1950, 1958).

Occurrence in North Greenland. Prinsesse Ingeborg Halv $\emptyset$, Foldedal Formation, GI 72168), Rauserites ex. gr. simplex assemblage.

Material. Three tangential oriented sections and some randomly oriented sections.

\section{Genus Schellwienia Staff \& Wedekind, 1910}

Schellwienia arctica (Schellwien, 1908)

Plate 3, Figs 6-9, 11

1908 Fusulina arctica Schellwien, p. 173, pl. 16, figs 3-9.

1960 Triticites arcticus (Schellwien) Forbes, p. 216, pl. 32, figs 10-17

1962 Pseudofusulina (Rugosofusulina) arctica (Schellwien) Ross \& Dunbar (part), p. 41, pl. 6, figs 1, 2, 5-7.

Stratigraphical distribution. Upper Gzhelian in the Urals, Central Asia, Donets basin (Davydov in Chuvashov et al., 1986), upper Gzhelian - lower Asselian in the Tyrrellfjellet Member of Spitsbergen (Nilsson, 1993) and Finnmark Platform (Nilsson, 1993), lower Asselian in the Kapp Duner Formation of Bjørnøya (Simonsen, written communication 1988).

Occurrence in North Greenland. Holm Land and Amdrup Land, Kim Fjelde Formation, samples E 131 1/2, E 138 , E 139 and F2-X of Ross \& Dunbar (1962), Schellwienia arctica assemblage.

Material. Three axial oriented sections and some oblique oriented sections.

\section{Schellwienia amdrupensis (Ross \& Dunbar, 1962)}

Plate 3, Figs 12, 15, 17

1962 Pseudofusulina (Daixina) amdrupensis Ross \& Dunbar, p. 39,40 , pl. 6, figs 14-16.

Stratigraphical distribution. Lower Permian in eastern North Greenland (Dunbar et al., 1962), Asselian in the Kapp Duner Formation of Bjørnøya (Simonsen, written communication 1988).

Occurrence in North Greenland. Amdrup Land, Kim Fjelde Formation, sample F2-115 of Ross \& Dunbar (1962), Sphaeroschwagerina aff. S. vulgaris assemblage.

Material. Three axial oriented sections.

\section{Plate 5}

All figures $\times 10$, except noted

Figs 1-4. Schwagerina ex. gr. exuberata (Shamov); 1-4, GI-72150.

Figs 5,8,10,14. Sphaeroschwagerina sp.; 5, 8, 14, GGU-220366; 10, GI-72150.

Fig. 6. Eoparafusulina? aff. E. domesticus (Grozdilova \& Lebedeva); 6, GGU-220366.

Fig. 7. Sphaeroschwagerina sphaerica gigas (Rauser-Chernobova \& Scherbovich); 7, sample 191 of Dunbar et al. (1962).

Fig. 9. Pseudofusulinella sp. B; 9, GI-72150, $\times 20$.

Fig. 11. Sphaeroschwagerina ex. gr. sphaerica (Scherbovich); 11, sample 191 of Dunbar et al. (1962).

Figs 12,13. Schubertella transitoria Staff \& Wedekind; 12, GGU-220366; 13, GI-72148, both $\times 40$. 


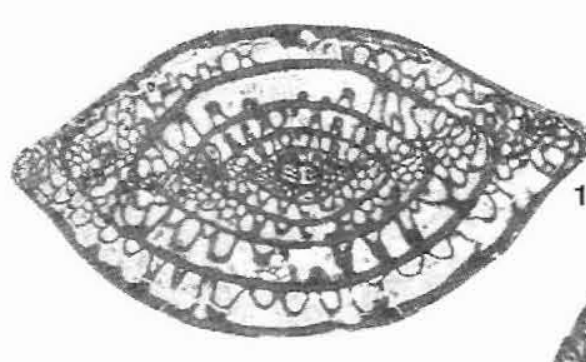

\section{Plate 5}

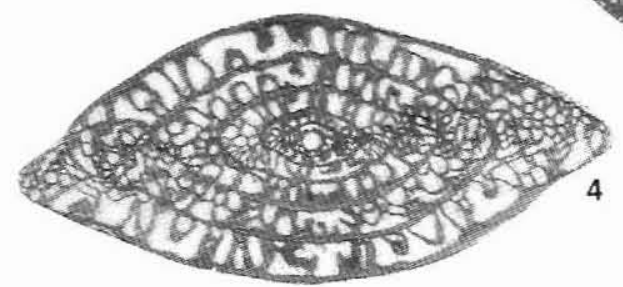

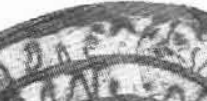

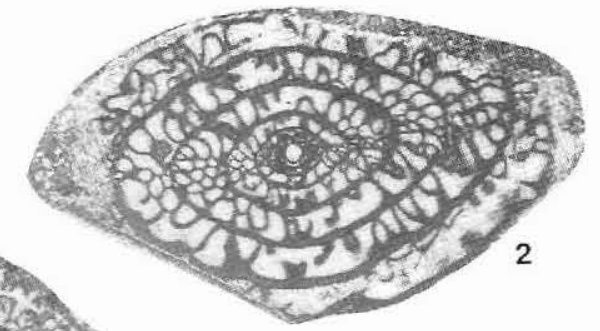

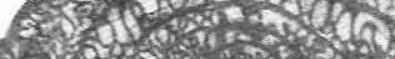

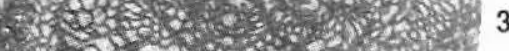

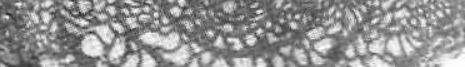

3
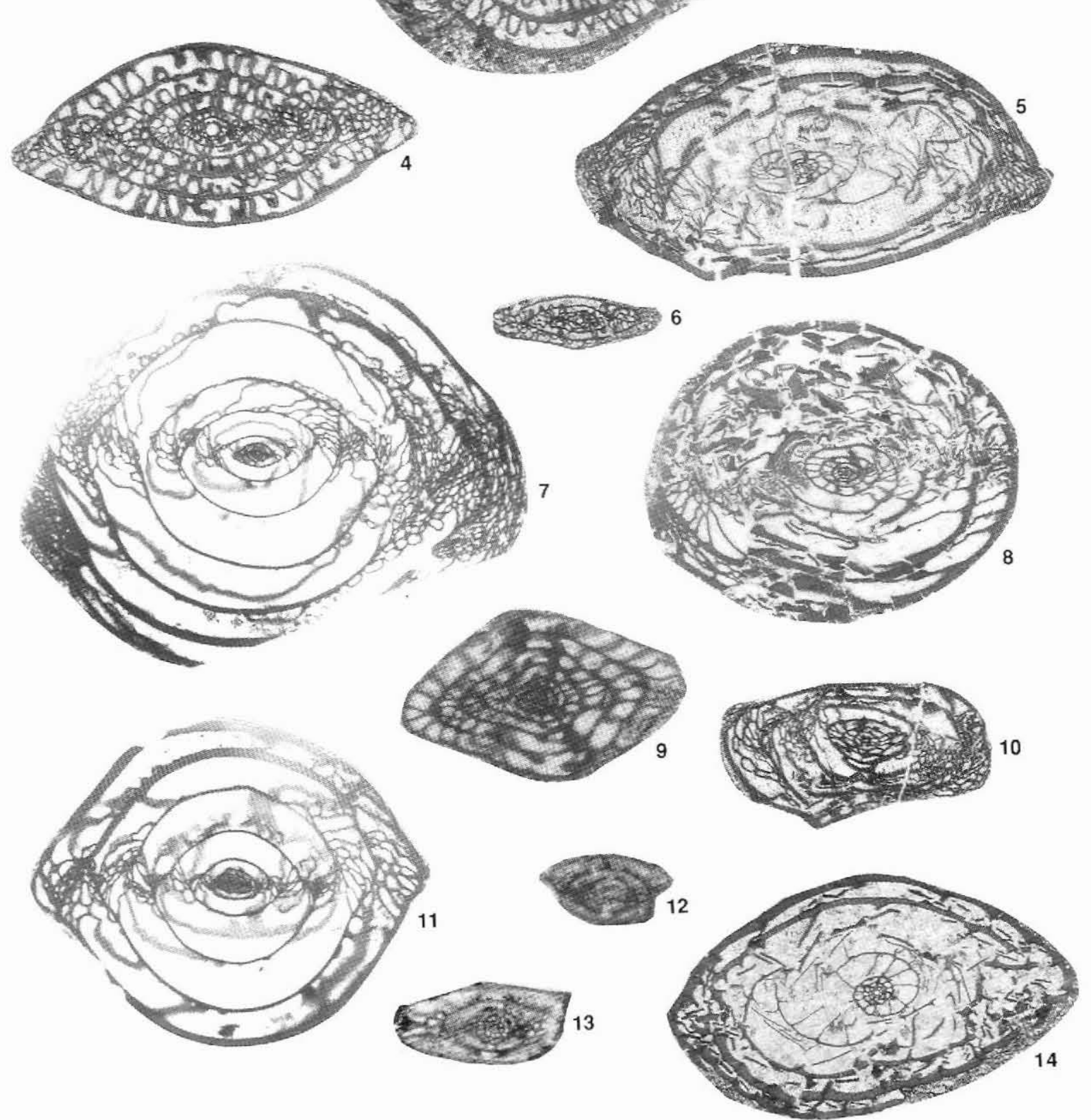
Genus Schwagerina von Möller, 1877 Schwagerina ex. gr. exuberata (Shamov, 1958)

Plate 5, Figs 1-4

Stratigraphical distribution. Lower Permian (middle-upper Asselian) in Russia (Shamov, 1958; Sjomina, 1961) and Spitsbergen (Nilsson, 1993).

Occurrence in North Greenland. Prinsesse Ingeborg Halv $\varnothing$, Kim Fjelde Formation, GI 72150, Schwagerina aff. S. moelleri - S. ex. gr. exuberata assemblage.

Material. One axial oriented section, one oblique oriented section and four tangential oriented sections.

\section{Schwagerina aff. S. gracilis (Sjomina, 1971)}

Plate 4, Figs 9, 10, 13

Remarks. Ross \& Dunbar (1962) identified these specimens as Schwagerina krotowi (Schellwien). However, part of their figured specimens (figs 10-13 in pl. 6) are more closely related to Schwagerina gracilis group of Sjomina (1971).

Stratigraphical distribution. Lower Asselian in the Russian Platform and Urals (Kireeva et al., 1971; Chuvashov et al., 1986), upper Gzhelian in South Ural (Davydov et al., 1990), upper Gzhelian - lower Asselian in Finnmark Platform and Spitsbergen (Nilsson, 1993).

Occurrence in North Greenland. Amdrup Land, Kim Fjelde Formation, sample 214b (loose block) of Ross \& Dunbar (1962).

Material. Three axial oriented sections and one tangential oriented section.

\section{Schwagerina aff. S. moelleri (Schellwien, 1908)}

Plate 4, Fig. 8

Stratigraphical distribution. Schwagerina moelleri (Schellwien) is an index species for the lower Sakmarian strata in the Timan-Pechora Basin of Russia (Grozdilova \& Lebedeva, 1961; Konovalova, 1991).

Occurrence in North Greenland. Prinsesse Ingeborg Halvø, Kim Fjelde Formation, GI 72148, Schwagerina aff. $S$. moelleri $-S$. ex. gr. exuberata assemblage.
Material. One axial oriented section and two randomly oriented sections.

\section{Schwagerina ex. gr. nathorsti (Staff \&} Wedekind, 1910)

Plate 4, Figs 4, 5, 7

Remarks. The subrhomboidal shell with distinct pseudochomata shows similarities to the types of Schwagerina nathorsti (Staff \& Wedekind) from Bjørnøya, but the investigated specimens are different from the type specimens in having a shorter shell and more inflated test.

Stratigraphical distribution. Schwagerina nathorsti (Staff \& Wedekind) is present in middle-upper Asselian strata on Bjørnøya (Simonsen, written communication 1988, Nakrem et al., 1992) and Spitsbergen (Nilsson, 1988, 1993).

Occurrence in North Greenland. Prinsesse Ingeborg Halvø, Kim Fjelde Formation, GI 72144, Schwagerina ex. gr. nathorsti assemblage.

Material. Two slightly oblique oriented section and two randomly oriented sections.

\section{Schwagerina plicatissima (Rauser-} Chernousova, 1940)

Plate 6, Figs 7-10

1940 Pseudofusulina plicatissima Rauser-Chernousova, p. 87 , pl. 4 , figs 5,6 , pl. 5 , figs $1-3$.

Stratigraphical distribution. Lower Permian (upper Sakmarian) in the Timan-Pechora Basin (Grozdilova \& Lebedeva, 1961; Konovalova, 1991).

\section{Plate 6}

All figures $\times 10$

Figs 1-3. Rugosochusenella sp. A; 1, 2, 3, GGU 220366.

Fig. 4. Rugosochusenella ex. gr. paragregaria (Rauser-Chernousova); 4, loose block-sample of Dunbar et al. (1962).

Fig. 5. Rugosochusenella gregarieformis (Rauser-Chernousova \& Scherbovich); 5, loose block-sample of Dunbar et al. (1962).

Fig. 6. Eoparafusulina cf. E. paralinearis (Thorsteinsson); 6, loose block-sample of Dunbar et al. (1962).

Figs 7-10. Schwagerina plicatissima (Rauser-Chernousova); 7 , 8, 9, 10, GI 72151 .

Fig. 11. Schwagerina sp. B; 11, GI 72151. 


\section{Plate 6}
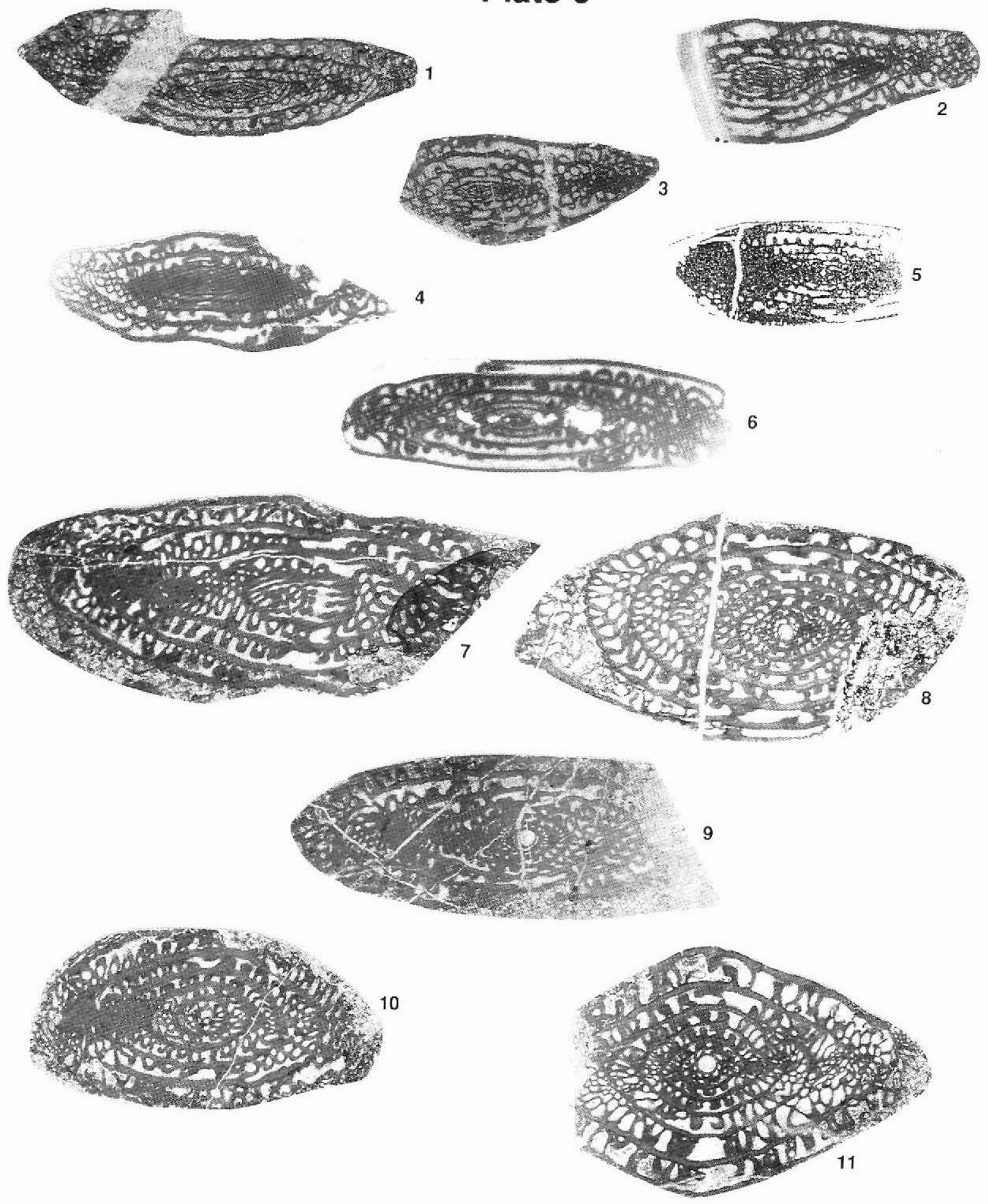
Occurrence in North Greenland. Prinsesse Ingeborg Halvø, Kim Fjelde Formation, GI 72151, Schwagerina plicatissima assemblage.

Material. Two slightly oblique oriented sections, one saggital oriented section and several tangential and randomly oriented sections.

Schwagerina ex. gr. princeps (Ehrenberg, sensu Dunbar \& Skinner, 1936)

Plate 4, Figs $15,17,18$

Stratigraphical distribution. Middle-upper Asselian in Spitsbergen (Nilsson, 1993).

Occurrence in North Greenland. Amdrup Land, Kim Fjelde Formation, sample 178 (loose block) of Dunbar et al. (1962) and Prinsesse Ingeborg Halvø, Kim Fjelde Formation, GGU 220366, Schwagerina aff. S. moelleri$S$. ex. gr. exuberata assemblage.

Material. Two axial and one oblique oriented sections.

\section{Schwagerina pseudokaragasensis Petocz, 1970}

Plate 4, Figs 1-3

1970 Schwagerina pseudokaragasensis Petocz, p. 43-46, pl 1 , figs 19-26.

Stratigraphical distribution. Lower Permian (upper Asselian - middle Sakmarian) in east-central Alaska Range (Petocz, 1970).

Occurrence in North Greenland. Prinsesse Ingeborg Halvø, Kim Fjelde Formation, GI 72144, Schwagerina ex. gr. nathorsti assemblage.

Material. One slightly oblique oriented section, two tangential oriented sections and some randomly oriented sections.

\section{Schwagerina sphaerica (Belyaev, 1938)}

Plate 4, Fig. 14

1938 Pseudofusulina uralica var. sphaerica Belyaev in Belyav \& Rauser- Chernousova, p. 185-187, pl. 2, figs 5-7.

1961 Pseudofusulina sphaerica sphaerica (Belyaev) Grozdilova \& Lebedeva, p. 200-201, pl. 7, figs 5-6.

Remarks. In Nilsson et al. (1991) the recorded specimens were assigned to Schwagerina ex. gr. princeps. However, the investigated specimens are more closely related to Schwagerina sphaerica (Belyaev, 1937).

Stratigraphical distribution. Upper Asselian in the Urals (Belyaev \& Rauser-Chernousova, 1938; Shamov, 1958; Mikhailova, 1974), Timan-Pechora Basin (Grozdilova \& Lebedeva, 1961, Konovalova, 1991) and Spitsbergen (Nilsson \& Davydov, 1993; Nilsson, 1993).

Occurrence in North Greenland. Prinsesse Ingeborg Halvø, Kim Fjelde Formation, GI 72150, GGU 220366, Schwagerina aff. S. moelleri - S. ex. gr. exuberata assemblage.

Material. One axial oriented section, one slightly oblique oriented section and several randomly oriented sections.

\section{Schwagerina sp. A}

Plate 4, Figs 12, 16

Remarks. Specimen of 6.5 volutions reach length of 5.9 $\mathrm{mm}$ and diameter of $4.6 \mathrm{~mm}$, giving form ratio of 1.3 .

Proloculus is large, outside diameter 300 microns.

The large proloclulus, the coiling of the volutions and the shape of the test indicate some similarities to Schwagerina globosa (Schellwien \& Dyhrenfurth), but the septal fluting is less regular and the size of shell is much smaller. The recorded specimens of Schwagerina sp. A were incorrectly assigned as Schwagerina globosa (Schellwien \& Dyhrenfurth) by Nilsson et al. (1991).

Occurrence in North Greenland. Prinsesse Ingeborg Halvø, Kim Fjelde Formation, GGU 220366, Schwagerina aff. $S$. moelleri $-S$. ex. gr. exuberata assemblage.

Material. One axial oriented section and two tangential oriented sections.

\section{Schwagerina sp. B}

Plate 6, Fig. 11

Remarks. Specimen of 6.5 volutions has a length of 7.1 $\mathrm{mm}$ and a diameter of $4.1 \mathrm{~mm}$, which gives a form ratio of 1.7. The outside diameter of the proloculus measures 360 microns. The examined specimen shows some similarities to the Schwagerina uralica group of Rauser-Chernousova.

Occurrence in North Greenland. Prinsesse Ingeborg Halvø, Kim Fjelde Formation, GI 72151, Schwagerina plicatissima assemblage. 
Material. One axial oriented section and two randomly oriented sections.

\section{Genus Zigarella Davydov, 1982}

Zigarella anderssoni (Schellwien, 1908; non Rauser- Chernousova et al., 1936)

Plate 3, Fig. 18

1908 Pseudofusulina anderssoni Schellwien, p. 192, 193, no illustrations.

1910 Schellwienia anderssoni (Schellwien) Staff \& Wedekind, p. 119, 120, pl. 3, figs 1-5.

Stratigraphical distribution. Lower Asselian in Spitsbergen (Nilsson \& Davydov, 1993; Nilsson, 1993); middle Asselian in Bjørnøya (Simonsen, written communication 1988; Nakrem et al., 1991).

Occurrence in North Greenland. Southern Holm Land, Kim Fjelde Formation, sample E 138 of Ross \& Dunbar (1962).

Material. One axial oriented section and two randomly oriented sections.

\section{Genus Eoparafusulina}

Eoparafusulina cf. E. paralinearis

(Thorsteinsson, 1960)

Plate 6, Fig. 6

Stratigraphical distribution. Wolfcampian in the Sverdrup Basin (Thorsteinsson, 1960), lower Sakmarian in Spitsbergen (Cutbill \& Challinor, 1965; Nilsson \& Davydov, 1993; Nilsson, 1993).

Occurrence in North Greenland. Amdrup Land, loose block.

Material. One axial oriented section.

\section{Eoparafusulina? aff. E.? domesticus} (Grozdilova \& Lebedeva, 1961)

Plate 5, Fig. 6

Stratigraphical distribution. Lower Sakmarian in the Timan-Pechora Basin (Grozdilova \& Lebedeva, 1961; Konovalova, 1991).

Occurrence in North Greenland. Prinsesse Ingeborg Halvø, Kim Fjelde Formation, GGU 220366, Schwagerina aff. $S$. moelleri $-S$. ex. gr. exuberata assemblage.
Material. One slightly oblique section and one randomly oriented section.

Genus Rugosofusulina Rauser-Chernousova, 1937

Rugosofusulina arianica Leven \&

Scherbovich, 1978

Plate 3, Figs 13, 14, 16

1978 Rugosofusulina arianica Leven \& Scherbovich, p. 94, 95, pl. 4, figs $8,9$.

Stratigraphical distribution. Upper Gzhelian in the Donets Basin (Chuvashov et al., 1986); lower Asselian in Darvas (Leven \& Scherbovich, 1978).

Occurrence in North Greenland. Southern Holm Land, Kim Fjelde Formation, sample E 138 of Dunbar et al. (1962), Sphaeroschwagerina aff. S. vulgaris assemblage.

Material. Three axial oriented sections.

Rugosofusulina aff. $R$. eliptica Rosovskaya, 1958

Plate 2, Figs 1-3

Stratigraphical distribution. Gzhelian in the Urals (Rosovskaya, 1958).

Occurrence in North Greenland. Eastern Peary Land, Foldedal Formation, sample 183 of Petryk (1977), Rauserites ex. gr. rossicus assemblage.

Material. Five oblique oriented sections.

\section{Rugosofusulina aff. $R$. praevia Shlykova, 1948}

Plate 3, Figs $1-4$

Remarks. These specimens were assigned to 'Pseudofusulina (Rugosofusulina) arctica' (Schellwien) by Ross \& Dunbar (1962, p. 41-43, pl. 6, figs 3, 5). However, Schellwienia arctica (Schellwien) has no real rugosity in wall-structure, and specimens showing rugosity should not be included in that species.

Stratigraphical distribution. Upper Carboniferous (lower Gzhelian) in the Urals (Rosovskaya, 1958); Gzhelian in the Finnmark Platform (Nilsson, 1993).

Occurrence in North Greenland. Southern Holm Land, Kim Fjelde Formation, sample E 131 1/2 of Ross \& Dunbar (1962), Schellwienia arctica assemblage. 
Material. Three axial oriented and one oblique oriented sections.

\section{Genus Rugosochusenella Skinner \& Wilde, 1965}

Rugosochusenella ex. gr. paragregaria (Rauser- Chernousova, 1940)

Plate 6, Fig. 4

Remarks. This specimen was included in Pseudofusulina (Rugosofusulina) sp. A of Ross \& Dunbar (1962, pl. 7, fig. 4).

Stratigraphical distribution. Uppermost Gzhelian in Darvas (Chuvashov et al., 1986) and Asselian in the Russian Platform and Urals (Rauser-Chernousova, 1940).

Occurrence in North Greenland. Henrik Kröyer Holme, ?Kim Fjelde Formation, sample 191 (loose block) of Ross \& Dunbar (1962).

Material. One axial oriented section.

\section{Rugosochusenella gregarieformis (Rauser- Chernousova \& Scherbovich, 1958)}

Plate 6, Fig. 5

1958 Pseudofusulina gregarieformis Rauser-Chernousova \& Scherbovich, p. 34, 35, pl. 2, figs 11, 12.

1962 Pseudofusulina (Rugosofusulina) sp. A Ross \& Dunbar (part), p. 43-45, pl. 7, fig. 2 .

Stratigraphical distribution. Uppermost Gzhelian in South Ural and lower Asselian in the Russian Platform (Chuvashov et al., 1986).

Occurrence in North Greenland. Kap Jungersen, ?Kim Fjelde Formation, sample 112 (?loose block ) of Ross \& Dunbar (1962).

Material. One axial oriented section.

\section{Rugosochusenella sp. A}

Plate 6, Figs 1-3

Stratigraphical distribution. Rugosochusenella is present in Lower Permian (Asselian-Sakmarian) strata (e.g. Loeblich \& Tappan, 1988).

Occurrence in North Greenland. Prinsesse Ingeborg Halv $\emptyset$, Kim Fjelde Formation, GGU 220366, Schwagerina aff. $S$. moelleri $-S$. ex. gr. exuberata assemblage.
Material. One slightly oblique oriented section and five tangential oriented sections.

Acknowledgements. The participants of the Fusulinid study project at IKU Petroleum Reasearch: A/S Norske Shell, Amoco Norway Oil Company, Esso Norge a.s., Mobil Exploration Norway Inc., are gratefully acknowledged. The Geological Survey of Greenland, and especially Lars Stemmerik, are thanked for providing sample material and for co-operation during this study. Vladimir I. Davydov (St. Petersburg) has given comments to the taxonomic and biostratigraphic conclusions, and Stefan Piasecki (GGU, Copenhagen) commented on an early version of the manuscript.

\section{References}

Belyaev, G. M. \& Rauser-Chernousova, D. M 1938: O nekotoych fuzuliniack schwagerinovogo gorizonta (gruppa Pseudofusulina uralica Krotow) [On some fusulinids of the Schwagerina Horizont (the group Pseudofusulina uralica Krotow)]. Trudy Geol. Inst. Akad. Nauk SSSR, 7, 169-196.

Chen, S. 1934: Fusulinidae of South China. Part I. Paleont. Sinica, Ser. B, 4, Fasc. 2, 133 pp.

Chuvashov, B. N., Leven, E. Ya. \& Davydov, V. I. 1986: Fuzulinidy verkhnego karbona i assel'skogo yarusa nizhney permi yuzhnogo Urala. In Chuvashov, B. N., Leven, E. Ya. \& Davydov, V. I. (ed.) Pogranichnye otlozheniya karbona $i$ permi Urala, Pri-Ural'ya i Sredniy Asii (Biostratigragiya $i$ korrelytsiya) [Fusulinids of the Upper Carboniferous and the Asselian Stage of the Lower Permian in the southern Urals], 77-102. Moscow: Akad. Nauk. SSR, Ural'skiy nauchiy tsentr.

Cutbill, J. L. 1968: Carboniferous and Permian stratigraphy of Ny-Friesland. Spitsbergen. Norsk Polarinst. Årbok, 1966, $12-24$.

Cutbill, J. L. \& Challinor, A. 1965: Revision of the stratigraphical scheme for the Carboniferous and Permian rocks of Spitsbergen and Bjørnøya. Geol. Mag. 102, 418-439.

Davydov, V. I. 1982: Zonal'nye i yarusnye podrazdeliniya po fuzulinidam verkhnego Karbona yugozapaldnogo Darvoza. Spetsial'nost' 04.00.09 - Paleontologiya i Stratigrafiya, Kandidata Geologo [Zone and stage subdivisions based on fusulinids of the Upper Carboniferous in the south-western Darvaz] - Mineralogicheskikh nauk, Leningrad, 3-20.

Davydov, V. I. 1986: Fuzulinidy verkhnego karbona i assel'skogo yarusa nizhney permi yushnogo Urala. In Chuvashov, B. N., Leven, E. Ya., Davydov, V. I. (ed.) Pogranichnye otlozheniya karbona i permi Urala, Pri-Ural'ya i Sredniy Asii (Biostratigragiya $i$ korrelytsiya) [Fusulinids of the Upper Carboniferous and the Asselian Stage of the Lower Permian in the southern Urals], 103-125. Moscow: Akad. Nauk. SSR, Ural'skiy nauchiy tsentr.

Davydov, V. I., Bogoslovstaja, M. F., Popov, A. V., Akhmetshina, L. Z., Barskov, I., Kozitskaja, R. I., Kotlyar, G. V. \& Leven, E. Ya. 1990: The solution to the problem of the Carboniferous/Permian boundary in the USSR. Permophiles 17, 9-13 [a newsletter of Subcomm. Permian Stratigraphy]. Dunbar, C. O. \& Henbest, L. G. 1930: The fusulinid genera 
Fusulina, Fusulinella and Wedekindella. Amer. J. Sci. (5)20, 357-364.

Dunbar, C. O. \& Skinner, J. W. 1936: Schwagerina versus Pseudoschwagerina and Paraschwagerina. J. Paleont. 10(2), 83-91.

Dunbar, C. O, Troelsen, J., Ross, C., Ross, J. P. \& Norford, B. 1962: Faunas and correlation of the late Paleozoic rocks of Northeast Greenland. Part I. General discussion and summary. Meddr Gronland 167(4), 16 pp.

Dutkevich, G. A. 1934: Novye vydi fuzulinid iz verkhnego i srednego karbona Verkhne-Chusovskykh gorodkov (Zapadniyi sklon Srednego Urala) [Some new species of fusulinidae from the Upper and Middle Carboniferous of Verkhne-Chussovskye Gorodky of the Chussovaya River (western slope of the Middle Ural)]. Trudy Vses. neft. nauchno-issled. Geol.razv. Inst. A, 36, 1-98.

Forbes, C. L. 1960: Carboniferous and Permian Fusulinidae from Spitsbergen. Palaeontology 2, 210-225.

Galloway, J. J. 1933: A manual of Foraminifera, 483 pp., 42 pls. Bloomington, Indiana.

Ginkel, A. S. van 1965: Carboniferous fusulinids from the Cantabrian Mountains (Spain). Leidse Geol. Meded. 34, 1225.

Girty, G. H. 1904: Triticites, a new genus of Carboniferous Foraminifers. Amer. J. Sci. (4) 17, 234-240.

Grozdilova, L. P. 1966: Foraminifery verkhnego Karbona severnogo Timana [The Upper Carboniferous foraminifera of northern Timan]. Trudy Vses. neft. nauchno-issled. Geol.razv. Inst. (VNIGRI) 250. Mikrofauna SSSR 14, 254-361.

Grozdilova, L. P.\& Lebedeva, N. S. 1961: Nizhnepermskie foraminiferysevernogo Timana [Lower Permian foraminifers of Northern Timan]. Trudy Vses. neft. nauchno-issled. Geol.razv. Inst. (VNIGRI) 179. Mikrofauna SSSR 13, 161-283.

Håkansson, E. \& Stemmerik, L. 1984: Wandel Sea Basin - the North Greenland equivalent to Svalbard and the Barents Shelf. In Spencer, A. M. et al. (ed.) Petroleum geology of the North European margin, 97-107. London: Graham \& Trotman for the Norwegian Petroleum Society.

Håkansson, E. \& Stemmerik, L. 1989: Wandel Sea Basin - a new synthesis of the Late Palaeozoic to Tertiary accumulation in North Greenland. Geology 17, 683-686.

Isakova, T. N. \& Nazarov, B. B. 1986: Stratigraphiya i mikrofauna pozdnego karbona-rannei permi Uzhnogo Urala [Stratigraphy and microfauna in the Late Carboniferous - Early Permian of the Southern Urals]. Trudy Geolo-gicheskogo inst. Akad. Nauk SSSR 402, 1-184.

Kahler, F. 1973: Beiträge zur Kenntnis der Fusuliniden der Ostalpen: Die Gattung Quasifusulina in den Karnischen Alpen. Palaeontographica Abt. A. 141, 154-173.

Kireeva, G. D., Scherbovich, S. F., Dobrokhotova, S. V., Ketat, O. B., Mal'kovskiy, F. S., Sjomina, S. A., Chernova, I. A. \& Yagofarova, F. Z. 1971: Zona Schwagerina vulgaris i Schwagerina fusiformis Assel'skogo yarusa russkoy platformy i zapadnogo sklona yuzhnogo Urala [The Schwagerina vulgaris and Schwagerina fusiformis zones of the Asselian Stage of the Russian Platform and the western slope of the South Urals]. Voprosy Mikropaleont. 14, 70-102.

Konovalova, M. V. 1991: Stratigraphiya i fuzulinidy verkhnego karbona i nizhneyi permi Timano-Pechorskoyi neftegazonosnoyi provintsii [Stratigraphy and fusulinids in the Upper Carboniferous and Lower Permian in the Timan-Pechora oil-gas bearing Province], 201 pp. Moscow: Ministerstvo Geologii SSSR.

Lebedeva, N. S. 1966: Foraminifery srednegi karbon severnogo Timana [Foraminifers of the Middle Carboniferous in northern Timan]. Trudy Vses. neft. nauchno-issled. Geol.-razv. Inst. (VNIGRI) 250. Mikrofauna SSSR 14, 176-253.

Leven, E. Ya. \& Scherbovich, S. F. 1978: Fuzulinidy i stratigrafiya Assel'skogo yarusa Darvaza [Fusulinids and stratigraphy of the Darvaz Asselian stage], 163 pp. Moscow: Nauka.

Loeblich, A. R. \& Tappan, H. 1988: Foraminiferal genera and their classification, $869 \mathrm{pp}$. Van Nostrand Reinhold Company Inc.

Mikhailova, Z. P. 1974: Fuzulinidy verkhnego karbona Pechorskogo Priuraliya [The fusulinids of the Upper Carboniferous of Pechora Preurals], 116 pp. Inst. geol. Komi filiala, Akademii Nauk SSSR.

Miklukho-Maclay, A. D. 1949: Verkhnepaleozoyskiye fuzulinidy Sredney Azii [Upper Paleozoic fusulinids of the Middle Asia], 111 pp. Leningrad: Darvaz, Fergana, pamir. Izd-vo, Univ.

Miklukho-Maclay, A. D. 1959: Znachenie gomeomorphii dlya sistematiki fuzulinid [The significance of homeomorphy for the systematics of the fusulinid]. Uch. Zap. Leningr. Univ. 268(10), 155-172.

Möller, V. von 1877: Ubber Fusulinen und ähneliche Foraminiferen - Formen des russischen Kohlenkalks. Neues Jahrb. Min. Geol. Pal. 1877, 139-146.

Möller, V. von 1878: Die spiral-gewundenen Foraminiferen des russischen Kohlenkalkes. Mem. Acad. Sci., St. Petersbourg (7) 25, $147 \mathrm{pp}$.

Nakrem, H. A., Nilsson, I. \& Mangerud, G. 1992: Permian biostratigraphy of Svalbard (Arctic Norway) - a review. International Geology Review 34(9), 933-959.

Nassichuk, W. W. \& Wilde, G. L. 1977: Permian fusulinaceans and stratigraphy at Blind Fiord, southwestern Ellesmere Island. Bull. geol. Surv. Can. 268, 1-59.

Nilsson, I. 1988: Carboniferous and Permian fusulinids on the Nordfjorden block, Spitsbergen (Svalbard). Unpublished cand. scient. thesis, Univ. Oslo, $159 \mathrm{pp}$.

Nilsson, I. 1993: Upper Paleozoic fusulinid-stratigraphy of the Barents Sea and surrounding areas. Unpublished dr. scient. thesis, Univ. of Troms $\varnothing, 538 \mathrm{pp}$.

Nilsson, I. \& Davydov, V. I. 1993: Middle Carboniferous Lower Permian fusulinid stratigraphy in Spitsbergen, Arctic Norway - a framework for correlation in the Arctic. Abstract, Carboniferous to Jurassic Pangea conference, Calgary, 223 only.

Nilsson, I., Håkansson, E., Madsen, L., Pedersen, S. A. S. \& Stemmerik, L. 1991: Stratigraphic significance of new fusulinid samples from the Upper Palaeozoic Mallemuk Mountain Group, North Greenland. Rapp. Gronlands geol. Unders. 150, 29-32.

Petocz, R. G. 1970: Biostratigraphy and Lower Permian Fusulinidae of the Upper Delta River area, east-central Alaska Range. Spec. Pap. geol. Soc. Am. 130, 94 pp.

Petryk, A. A. 1977: Upper Carboniferous (Late Pennsylvanian) 
microfossils from the Wandel Sea Basin, Peary Land, eastern North Greenland. Rapp. Gronlands geol. Unders. 85, 16-21. Rauser-Chernousova, D. M. 1938: Verkhnepaleozoyskie foraminifry Samarskoy Luki Zavolzh'ya [The Upper Paleozoic foraminifera of the Samara Bend and the trans-Volga region]. Trudy Paleont. Inst. Akad. Nauk SSSR 7, 69-167.

Rauser-Chernousova, D. M. 1940: Stratigrafiya verkhnego karbona i artinskogo yarusa zapadnogo sklona Urala i materialy $\mathrm{k}$ faune fuzulinid [Stratigraphy of Upper Carboniferous and Artinskian of western slope of Urals and materials to fusulinids fauna]. Trudy Geol. Inst. Akad. Nauk SSSR 7, Geol. Ser. 2, 37-101.

Rauser-Chernousova, D. M. \& Scherbovich, S. F. 1949: Schvageriny evropeyskoy tsasti SSSR [Schwagerina in the European part of the USSR]. Trudy Geol. Inst. Akad. Nauk SSSR 105, Geol. Ser. 35, 61-117.

Rauser-Chernousova, D. M. \& Scherbovich, S. F. 1958: O shvagerinovom gorizonte tsentral'noyi chasti Russkoi Platformy [Schwagerins horizons of the central part Russian Platform]. Trudy Paleont. Inst. Akad. Nauk. SSSR 13, 3-56.

Rauser-Chernousova, D. M., Belyaev, G. M. \& Reitlinger, E. A. 1936: Verkhnepaleozoyiskie foraminifery Pechorskogo kraya [Upper Paleozoic foraminifers of the Pechora area]. Trudy polyarnoyi komissii Akad. Nauk SSSR 28, 152-232.

Rauser-Chernousova, D. M., Kireeva, G. D., Leontovich, G. E., Grizlova, N. D., Safonova, T. P \& Lernova, E. I. 1951: Srednekamernnougol'nye fusulinidy Russkoy Platformy $i$ Sopredel'nykh Oblastey [Middle Carboniferous fusulinids of the Russian Platform and adjaecent regions], $380 \mathrm{pp}$. Akademiya Nauk SSSR, Institut Geologicheskikh Nauk, Ministerstvo Neftyana Promyshlennost SSSR.

Rauser-Chemousova, D. M., Ivanova, E. A., Grozdilova, L. P. \& Makhlina, M. K. 1979: The Upper Carboniferous Series. In Wagner, R. H., Higgins, A. C. \& Meyen, S. V. (ed.) The Carboniferous of the USSR. Yorkshire Geol. Soc. Occasional Publ. 4, 147-174.

Rosovskaya, S. E. 1949: Novye predstaviteli fuzulinid v verkhne-kamennougol'nykh otlozheniyakh Uzhnogo Urala [New representatives of fusulinids from the Upper Carboniferous of the Southern Urals]. Gosgeolizdat. Trudy 13, 61-70.

Rosovskaya, S. E. 1950: Rod Triticites, ego razvitiye i stratigraficheskoge znacheniye [The genus Triticites, its development and stratigraphic significance]. Trudy Paleont. Inst. Akad. Nauk. SSSR 26, 3-78.

Rosovskaya, S. E. 1958: Fuzulinidy i biostratigraphicheskoe paschlenenie verkhnekamennougol'nykh otlozheniyi Samarskoyi Luki [Fusulinids and biostratigraphic subdivision of Upper Carboniferous of Samara Bend]. Trudy Paleont. Inst. Akad. Nauk. SSSR 13, 57-120.

Ross, C. A. \& Dunbar, C. O. 1962: Faunas and correlation of the Late Paleozoic rocks of Northeast Greenland. Part II. Fusulinidae. Meddr Gronland 167(5), 65 pp.

Rui Lin, Ross, C. A. \& Nassichuk, W. N. 1991: Upper Mošcovian (Demoinesian) Fusulinaceans from the type section of the Nansen Formation, Ellesmere Island, Arctic Archipelago. Bull. geol. Surv. Can. 418, 121 pp.

Schellwien, E. 1908: Monographie der Fusulinen. 1. Die Fusuli- nen des russisch-arktischen Meeresgebietes. Palaentographica 55, 145-194.

Schellwien, E. \& Dyhrenfurth, G. 1909: Monographie der Fusulinen. Teil II: Die asiatischen Fusulinen. A. Die Fusulinen von Darwas. Palaeontographica 56, 137-176.

Schellwien, E. \& Staff, H. 1912: Die Fusulinen (Schellwien) Nordamerikas. Palaeontographica 59, 157-191.

Schlykova, T. I. 1948: Fuzulinidy verkhego karbona samarskoy luki [Fusulinids of the Upper Carboniferous in the Samarian crescent]. Trudy Vses. neft. nauchno-issled. Geol.-ravz. Inst. (VNIGRI) 31. Mikrofauna SSSR 1, 109-143.

Shamov, D. F. 1958: Gruppa vzdyto-veretenoobpaznikh iz schvagerinovogo horizonta Ishimbaevao-Sterlitamakskogo neftenosnogo rayona [The group of swell and spindel-shaped pseudofusulinids of the Schwagerina horizon in the Ishimbaevao-Sterlitamak oil region]. Trudy Geol. Inst. Akad. Nauk SSSR 13, 139-154.

Sheng, J-C. 1951: Taitzehoella, a new genus of fusulinid. Bull. geol. Soc. China 31 (1-4), 79-84.

Sheng, J.-C. 1958: Some Fusulinids from the Maokou Limestone of Chinghai Province, northwestern China. Acta Paleont. Sinica, 6(3), 268-280 [Chinese], 280-290 [English].

Sjomina, S. A. 1961: Stratigraphiya i foraminifery (fuzulinidy) shvagerinovogo gorizonta Oksko-Tsninskogo podniatiya [Stratigraphy and foraminifers (fusulinids) of the schwagerins-horizon of Oksko-Tsninskogo dome]. Trudy Geol. Inst. Akad. Nauk SSSR 57, 3-57.

Skinner, J. W. \& Wilde, G. L. 1965: Permian biostratigraphy and fusulinid faunas of the Shasta Lake area, northern California. Kansas Univ. Paleontol. Contrib., Protozoa, art. 6, 1-98.

Staff, H. \& Wedekind, R. 1910: Der Oberkarbone Foraminiferensapropelit Spitzbergens. Bull. geol. Inst. Univ. Uppsala 10 , 81-123.

Stemmerik, L. \& Håkansson, E. 1989: Stratigraphy and depositional history of the Upper Palaeozoic and Triassic sediments in the Wandel Sea Basin, eastern North Greenland. Rapp. Grønlands geol. Unders. 143, 21-45.

Stemmerik, L. \& Håkansson, E. 1991: Carboniferous and Permian history of the Wandel Sea Basin, North Greenland. Bull. Grønlands geol. Unders. 160, 141-151.

Stemmerik, L. \& Worsley, D. 1989: Late Palaeozoic sequence correlations, North Greenland, Svalbard and the Barents Shelf. In Collinson, J. D. (ed.) Correlation in hydrocarbon exploration, 99-111. London: Graham and Trotman and the Norwegian Petroleum Society.

Suleimanov, I. S. 1949: Novye vidy fuzulinid podsemeystva Schubertellinae Skinner iz kamennougol'nykh i nezhnepermskikh otlozheniy bashkirskogo, Pre-Urala [New species of the fusulinid subfamily Schubertellinae Skinner in the Carboniferous and Lower Permian deposits of Bashkir, Pre- Ural]. Trudy Geol. Inst. Akad. Nauk. SSSR 35(105), 22-44.

Thompson, M. L. 1935: The fusulinid genus Staffella. Amer. J. Paleont. 9, 11-120.

Thompson, M. L. 1951: New genera of fusulinid Foraminifera. Contr. Cushman Foundation Foram. Res. 2(4), 115-119.

Thorsteinsson, R. 1960: Permian fusulinids of Grinnell Peninsula. In Harker, P. \& Thorsteinsson, R. (ed.) Permian rocks 
and faunas of Grinnell Peninsula, Arctic Archipelago. Mem. geol. Surv. Can. 309, 21-37.

Zolotova, V. P., Shcherbakova, M. V., Echlakov, Yu. A., Kosheleva, V. F., Alksne, A. E., Polozova, A. N. \& Konovalova, M. V. 1978: Fuzulinidy iz pogranychnikh otlozhenyi gzhel- 'skogo i assel'skogo yarusov Urala, Priuraliya i Timana [Fusulinids from Carboniferous/Permian boundary deposits of the Gzhelian and Asselian stages of the Urals, Preurals and Timan]. Voprosy Mikropaleont. 20, 93-120. 